\title{
Pietro Fiorini e la prospettiva su Bologna
}

\author{
Manuela Incerti \\ Paola Foschi
}

Abstract

Nel lungo corridoio che serviva l'antico dormitorio dell'ex-monastero di san Michele in Bosco di Bologna, è presente un singolare effetto chiamato, impropriamente, cannocchiale: allontanandosi dalla serliana che apre lo sguardo sulla città di Bologna, il rettangolo centrale della finestra inquadra perfettamente la torre degli Asinelli che apparentemente aumenta così di dimensioni. Attraverso la ricerca storico-documentale e gli strumenti del disegno ci si propone di indagare su questo fenomeno per chiarirne l'origine e le possibili ragioni.

Parole chiave

Pietro Fiorini, San Michele in Bosco, perspectiva, rilievo, distanze.

Paolo Battista Balbi, 17/4,

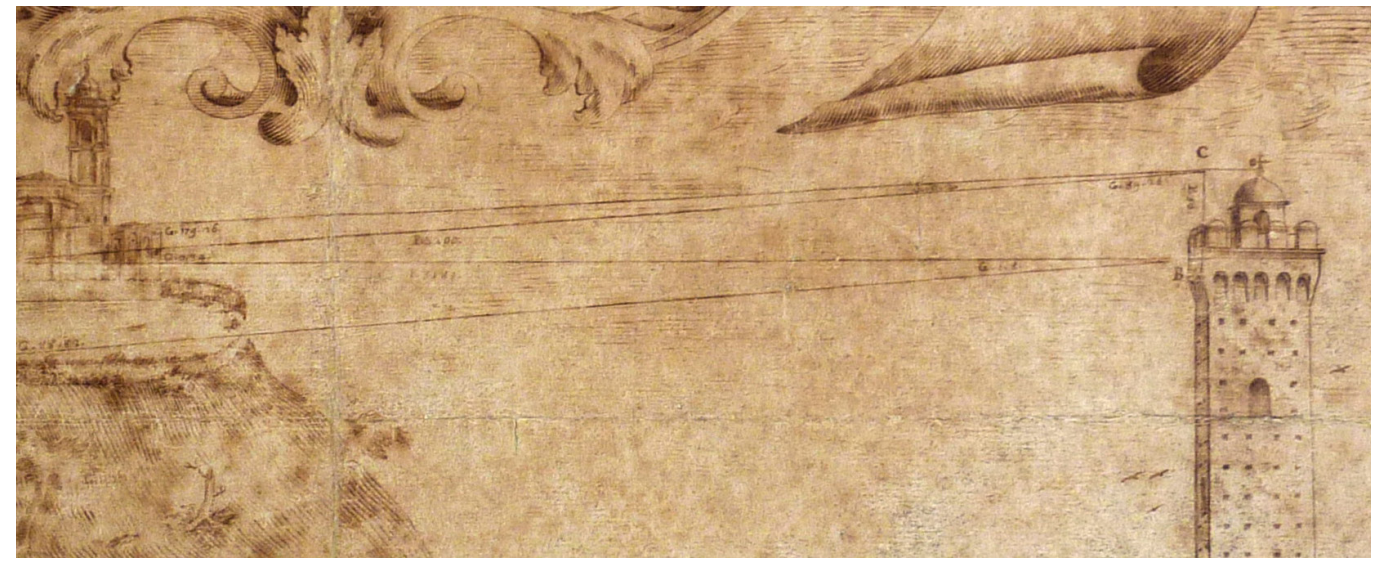




\section{L'architetto Pietro Fiorini (I539-1629) nel monastero di S. Michele in Bosco (PF)}

I lavori del tardo Cinquecento che diedero al monastero l'aspetto generale ancora oggi riconoscibile e la costruzione del grande braccio del dormitorio, con la serliana che inquadra la cima della Torre Asinelli, sono opera dell'architetto bolognese Pietro Fiorini. I libri di fabbrica del monastero attestano i suoi vari interventi nel grande complesso monastico olivetano.

II tema del fenomeno ottico detto "cannocchiale", che si verifica nel lungo dormitorio di S. Michele in Bosco osservando la torre Asinelli attraverso la finestra a serliana (fig. I), apre in realtà l'ampio tema dei lavori effettuati dall'architetto Pietro Fiorini [DBI 1997, pp. 205, 206] per gli Olivetani bolognesi fra gli anni ' 80 del Cinquecento e la fine del secondo decennio del Seicento [Foschi et al. 20 I7, pp. I 8 | - 189]. In questo esame ci soccorrono sia i libri di fabbrica del monastero [I] sia gli appunti biografici dell'architetto stesso, ora editi e commentati [2].

I suoi appunti elencano un consistente blocco di lavori, privi di indicazione cronologica esplicita, ma corredati dallindicazione del padre abate che li commissionò. Per prima cosa eseguì il chiostro grande con la cisterna centrale [3], l'andito (ingresso) principale, le scale maestre, la nuova foresteria; accomodò l'infermeria e costruì la stalla del padre abate, che era don Placido Fava ( I587; in seguito - specifica il Fiorini - eletto priore generale della congregazione olivetana e vescovo di Napoli) [4], e le stalle del monastero, al tempo del padre abate don Lorenzo Panara ( I600) e poi don Angelo Maria Cantoni ( I 60 I). II chiostro ottagonale fu commissionato dal padre abate don Onorato (Veli) nel I602 [5], e da p. Angelo Maria Cantoni, nel I605 [6].

Su richiesta del padre abate Greco (Pier Paolo da Galatina, I608) [7], cui poi seguì nel I6। I p. don Angelo Maria Cantoni, costruì le stanze nuove sotto al noviziato e il noviziato stesso. Ancora il p. Fava gli commissionò la fabbrica contigua al dormitorio con le logge e il cortile che fungeva da legnaia, e al piano di sopra le stanze utilizzate come foresteria. Lo stesso abate gli fece eseguire anche la cantina, la cucina, il forno e la riparazione del campanile, guastato da un fulmine. Questa serie di lavori deve distribuirsi nel corso degli anni dal I587, primo abbaziato del Fava, e il I 599, l'ultimo [8].

I libri di fabbrica registrano al 28 gennaio I 589 un pagamento al Fiorini di 10 scudi fiorentini per "havere messo in disegno la Pianta del nostro monastero", equivalenti a 4I lire di bolognini [9]. Al 1603 iniziano le registrazioni dei pagamenti per il chiostro ottagonale, definito anche «claustro della porta», commissionato dal p. Onorato Veli nel suo primo anno di abbaziato I 602 [10].

Fig. I.Vista della Torre degli Asinelli dal corridoio dell'ex-monastero (foto M. Incerti)

Fig. 2. Refettorio dell ex-monastero di San Michele in Bosco dell'Apocalisse eve del Apocalisse e vedute riquan monteri olivetani, riquadro del monastero
bolognese e particolare.
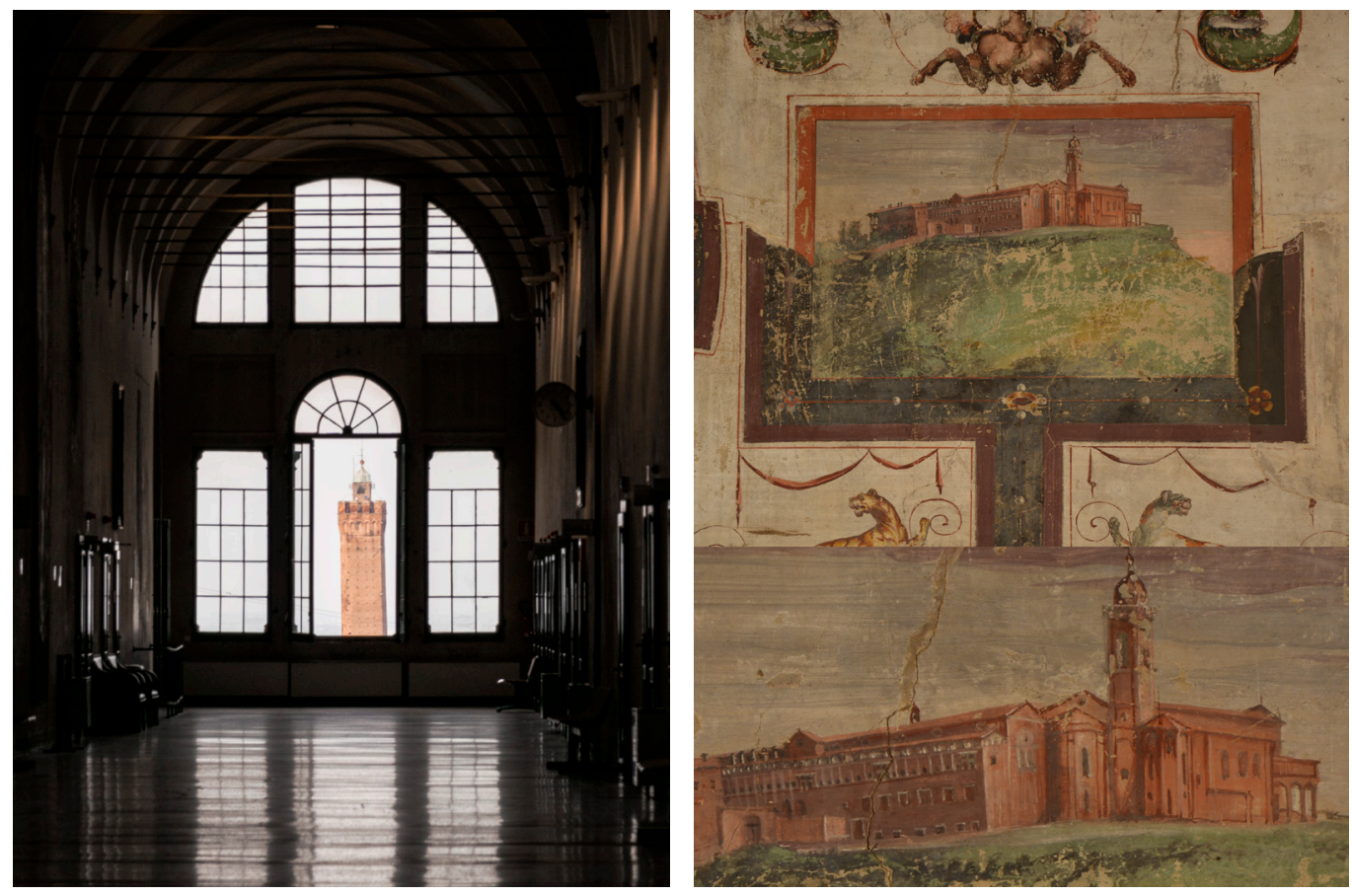
II Fiorini ricevette "per amorevolezza di commissione del molto reverendo padre abate" 26 lire e 2 soldi: non fu cioè pagato per lavori manuali o forniture di materiali, come gli altri artigiani, ma per un lavoro progettuale. Dal I 605 iniziarono i pagamenti per le pitture nel chiostro ottagonale [ I I], per la fabbrica del cortile, della cisterna e per una aggiunta al dormitorio. In quel periodo [12] a messer Pietro Fiorini furono versate in due rate 57 lire "per amorevolezza" e 2 lire 2 soldi per riparazioni. In seguito, nel 1612 , furono fatti lavori nel dormitorio nuovo verso i Cappuccini, per i quali gli furono versate 37 lire soldi 6 «per cortesia». L'ultimo lavoro ricordato è quello del noviziato nuovo nel 1613 : anche in questo caso furono versate "per amorevolezza" 30 lire 8 soldi 4 denari.

Dunque, il Fiorini lavorò sia al dormitorio nel 1587 che al dormitorio nuovo verso ponente, cioè verso il vicino convento dei Cappuccini (oggi sostituito da Villa Revedin), nel I606. Deve essere quindi stata sua l'idea della serliana, anche considerando che sia nella fabbrica del chiostro ottagonale che nel dormitorio vennero pagati ai tagliapietre vari architravi corinzi e architravi normali, nonché capitelli corinzi. La predilezione del Fiorini per la serliana, sia come finestra che come ordine caratterizzante dell'architettura, è già stata notata [13] e ricollegata allo stile di Domenico Tibaldi, i cui antenati lavorarono nel monastero nel corso del secolo precedente [Repishti 20 I I, pp. I29- I 4I]. In effetti I'archivista di S. Michele in Bosco nel I75I [Minucci I966, p. I7I] specificò che il più antico dormitorio era stato fabbricato nel I438, ma altri due bracci erano stati costruiti uno nel 1587, compreso il chiostro inferiore di mezzo, l'altro nel I606, comprese le stalle, cortile e cisterna.

La serliana compare invece in un disegno datato 5 marzo 1630 [Cartella Gozzadini 27, n. I4 I] che immortala il corteo di militari e compagnie civili bolognesi impegnati ad accompagnare il feretro del generale di Santa Madre Chiesa don Carlo Barberini [ [4] dal monastero alla chiesa di S. Michele in Bosco. II suo autore è Floriano dal Buono, incisore e disegnatore, ma anche pittore e scultore [15].

A queste testimonianze occorre aggiungere il disegno a volo d'uccello del I583 del monastero con i possessi fondiari circostanti che appartiene al cabreo delle possessioni delineato per gli Olivetani dal perito agrimensore Alfonso Nelli, operante dal I556 al I 628 [Periti agrimensori, indice], e il disegno e il calcolo relativo del rapporto dell'altezza della Torre Asinelli con il dormitorio di S. Michele in Bosco eseguiti nel I722 da Paolo Battista Balbi (I693- I 772) [I 6], fisico e anatomico illustre, aggregato e presidente dell'Accademia delle Scienze e dell'Accademia Benedettina.

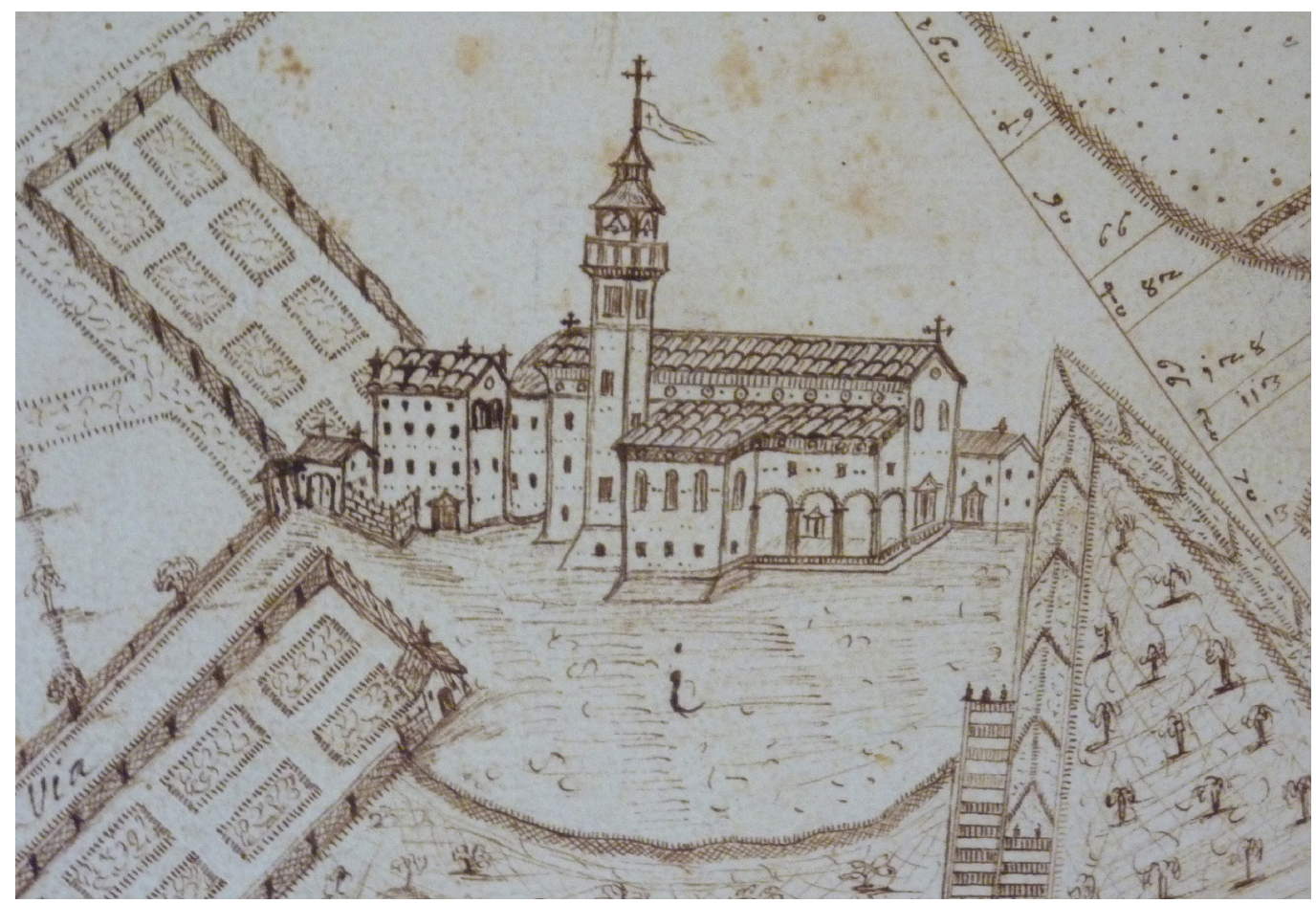




\section{La serliana e la torre degli Asinelli (MI)}

La più antica rappresentazione a noi nota del lato ovest del monastero, il lato occupato dal dormitorio dei monaci, risale agli anni I539- I540 e cioè all'incarico che il Vasari ricevette per decorare della grande sala del refettorio dei monaci (fig. 2). Come racconta l'artista nelle sue Vite, per questo importante spazio furono commissionate tre grandi tele da disporre di fronte alla porta di ingresso sul tema della carità fraterna e dell'ospitalità [17]. II programma decorativo comprendeva anche un fregio a grottesche con scene dall'Apocalisse e vedute dei monasteri olivetani d'Italia, che venne realizzato da tre suoi collaboratori: Cristoforo Gherardi, noto come il Doceno, Giovan Battista Cungi e Stefano Veltroni. Questa immagine cinquecentesca del monastero ci restituisce una rappresentazione del corpo di fabbrica delle celle provviste di loggia; la finestra del lungo corridoio che affaccia su Bologna è, indiscutibilmente, una bifora con oculo [18].

La medesima bifora compare in una seconda immagine, il disegno a inchiostro su carta conservato nell'Archivio di Stato di Bologna (fig. 3) già citato. In questo Cabreo delle Mappe e Piante de Beni, datato 1583, il dormitorio, anche se più stilizzato e in forte scorcio, termina sempre con una bifora con oculo.

La caratteristica serliana che contraddistingue oggi l'affaccio su Bologna compare invece nella veduta del 1630 sopra segnalata (fig. 4) e nel raffinato disegno su carta datato settembre 17/4 con cui Paolo Battista Balbi [19] illustra i calcoli topografici realizzati per stimare l'altezza della Torre degli Asinelli rispetto al pavimento del dormitorio di San Michele in Bosco (fig. 5). In alto, ai lati del titolo del disegno, sono due cartigli: a sinistra sono elencati i segmenti considerati (Tab. I), mentre sulla destra è la sintesi delle operazioni topografiche e lo svolgimento dei calcoli (Tab. 2).

Secondo l'autore di questo rilievo la differenza di quota tra i due elementi è pari a 32 piedi bolognesi (cioè 12, 16 metri [Martini I 883, p. 92]), mentre la distanza è di 3183 piedi (cioè 1209 metri).

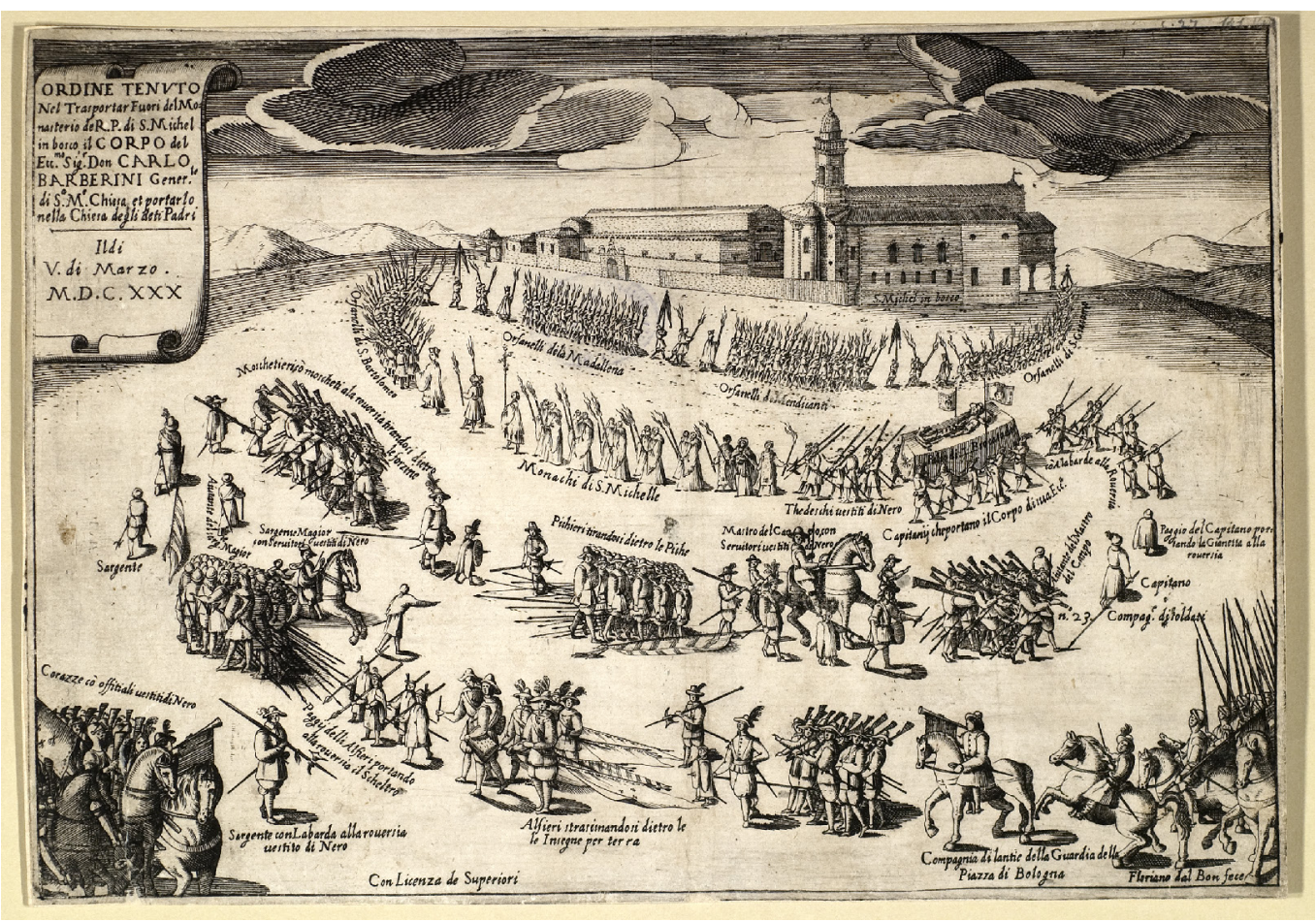


Tab. I Segmenti del calcolo topografico

$\mathrm{CH}$. Altezza torre degli Asinelli

CB. Elevazione della torre sopra il piano del dormitorio

AF. Altitudine colle di San Michele in Bosco

AK. Parte del dormitorio cui lunghezza è piedi 422

AE. Distanza dal fronte del dormitorio alla stazione E, oriente verso i prati, piedi 63

AD. Distanza tra il fronte del dormitorio alla stazione D in esso fatta piedi 200

AC. Distanza fronte del dormitorio al vertice della torre

AB. Distanza Torre al fronte del dormitorio

\begin{tabular}{|c|c|c|c|}
\hline & & & Note autore \\
\hline Soluzione triangolo ottusangolo ADC & & & $\begin{array}{l}\text { Applicazione del teorema dei seni (o di Eu- } \\
\text { lero): in un triangolo qualunque è costante } \\
\text { il rapporto tra la misura di un lato e il seno } \\
\text { dell'angolo opposto }\end{array}$ \\
\hline Seno angolo ACD & $0^{\circ} 32^{\prime}$ & 93083 & dalle tavole trigonometriche \\
\hline Lato AD in piedi & & 200 & \\
\hline Il prodotto di questi numeri & & $18.6 \mid 6.560$ & \\
\hline Seno angolo ACD & $0^{\circ} 02^{\prime}$ & 5.818 & dalle tavole trigonometriche \\
\hline Quoziente lunghezza $A C$ in piedi & & 3.200 & \\
\hline Soluzione triangolo rettangolo BAC & & & $\begin{array}{l}\text { Primo teorema sui triangoli rettangoli: la mi- } \\
\text { sura di un cateto è uguale al prodotto della } \\
\text { misura dell'ipotenusa per il seno dell'angolo } \\
\text { opposto }\end{array}$ \\
\hline Seno angolo BAC & $0^{\circ} 34^{\prime}$ & 98.900 & dalle tavole trigonometriche \\
\hline Lato $A C$ in piedi & & 3.200 & \\
\hline II prodotto di questi numeri & & 316.480 .000 & \\
\hline Raggio divisore & & 10.000 .000 & \\
\hline Quoziente lunghezza BC in piedi & & 31,6 & \\
\hline Soluzione triangolo rettangolo BEA & & & $\begin{array}{l}\text { Secondo teorema sui triangoli rettangoli: la } \\
\text { misura di un cateto è uguale a quella dell'altro } \\
\text { cateto per la tangente dell'angolo opposto }\end{array}$ \\
\hline Tangente angolo AEB & $88^{\circ} 52^{\prime \prime}$ & 505.485 .059 & dalle tavole trigonometriche \\
\hline Lato $A E$ in piedi & & 63 & \\
\hline Il prodotto di questi numeri & & 31.845 .558 .717 & \\
\hline Raggio divisore & & 10.000 .000 & \\
\hline Quoziente lunghezza $A B$ in piedi & & 3185 & \\
\hline Soluzione triangolo rettangolo $A C B$ & & & $\begin{array}{l}\text { la misura di un cateto è uguale a quella } \\
\text { dell'altro cateto per la tangente dell'angolo } \\
\text { opposto }\end{array}$ \\
\hline Tangente angolo BAC & $0^{\circ} 34^{\prime}$ & 98.905 & dalle tavole trigonometriche \\
\hline Lato $A B$ in piedi & & 3185 & \\
\hline II prodotto di questi numeri & & 315.012 .425 & \\
\hline Raggio divisore & & 10.000 .000 & \\
\hline Quoziente lunghezza $B C$ in piedi & & 32 & \\
\hline
\end{tabular}


Fig. 5. Paolo Battista Balbi, 17|4.Typus ostendens praxim adhibitam in excessu quaerendo Turris Asinellae supra pavimentum dormitorij monachorum divi Michaelis in Busco (BCABo, Gabinetto dei Disegni e Stampe, Cart. I, 3), (elaborazione grafica a cura di M. Incerti).

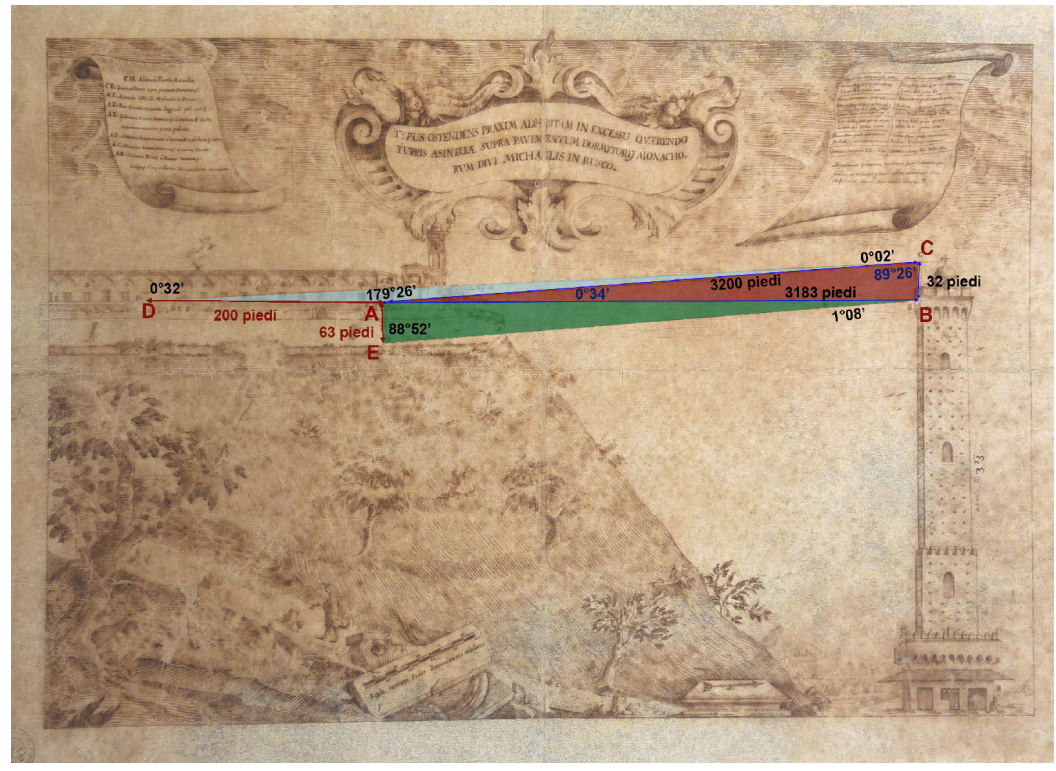

Nel rilevamento Balbi utilizza tre triangoli di cui uno ottusangolo e due rettangoli. La sequenza delle operazioni, eseguite con teodolite, può essere così riepilogata:

I) Dato il segmento AD pari a 200 piedi, vengono misurati gli angoli che si formano traguardando dai punti $A$ e $D$ la sommità della torre indicata con la lettera C [20]. La quota dello strumento in questi punti di stazione doveva essere almeno pari a quella del davanzale della serliana (alto circa I metro) o, più probabilmente, leggermente maggiore per poter agevolmente utilizzare lo strumento di misura. II rilievo laser scanner ci attesta che, a causa della pendenza del pavimento, alla quota di I,5 metri in A corrispondono I, 19 metri in D [2 I]. 2) Misurato l'angolo di $0^{\circ} 32^{\prime}$ in $\mathrm{D}$ e l'angolo di $179^{\circ} 26^{\prime}$ in $\mathrm{A}$, si ottiene per differenza il terzo angolo in $\mathrm{C}$ pari a $0^{\circ} 02$. Applicando il teorema dei seni è così possibile trovare la lunghezza del lato AC: dato AD pari a 200 piedi, si ottiene AC pari a 3200 piedi.

3) Considerato il triangolo rettangolo BAC (di cui si conosce ora l'ipotenusa pari a 3200 piedi) si misura l'angolo in $\mathrm{A}\left(0^{\circ} 34^{\prime}\right)$. Attraverso il primo teorema sui triangoli rettangoli si determina la lunghezza del lato $\mathrm{BC}$, cioè l'altezza della torre che sopralza il piano del pavi-

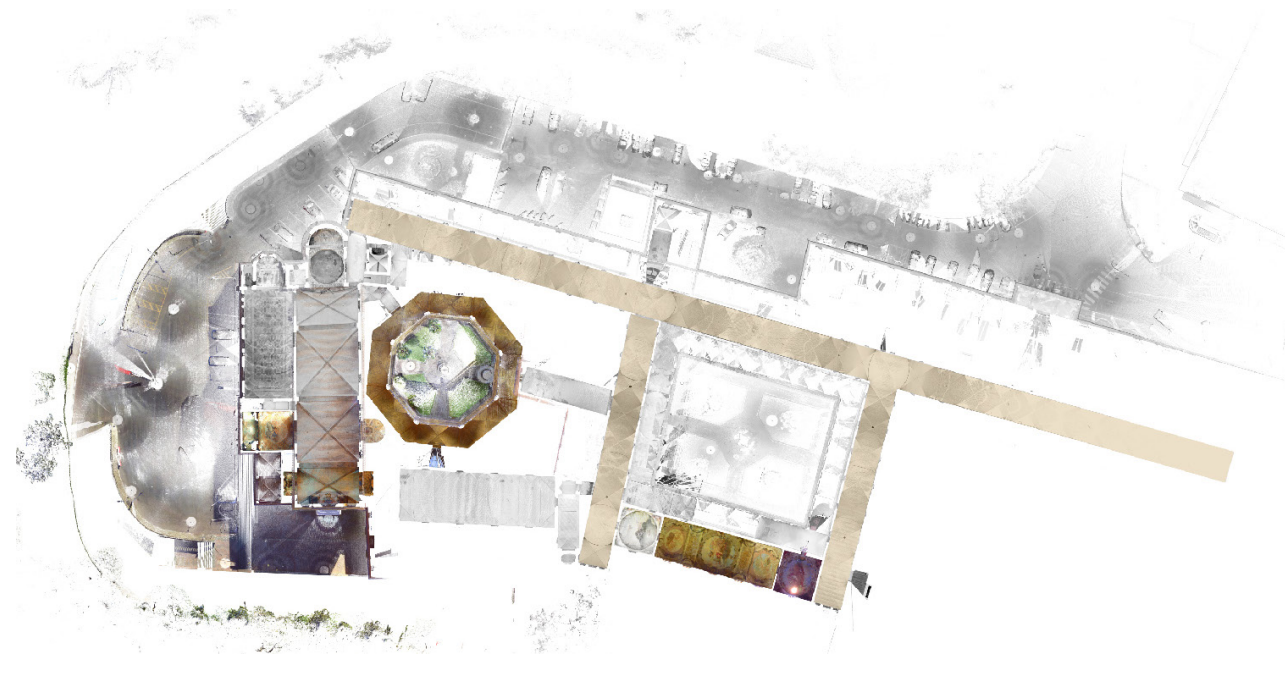

Fig. 6. Ortofoto tratta dalla registrazione del rilievo laser scanner (I 45 scansioni, Scene 2020, M. Incerti). II calcolo deg ambiente CAD e, date dimensioni dei triangoli considerati (1400 per metri circa) il disegno non è graficamente adeguato ad una canonica pagina di libro. 
Fig. 7. Fiorini annota che tra luglio e settembre de 1619 fece aggiustare la torre degli Asinelli e, con "occasione, misuro la sua bezza dala "cima dellar bala sino al piano di terr piedi 254 e $1 / 2$ ". La cupola e alta p. 8 d. 3 , il toresino piedi I5 (P. Fiorini, Diario, $\mathrm{AABO})$

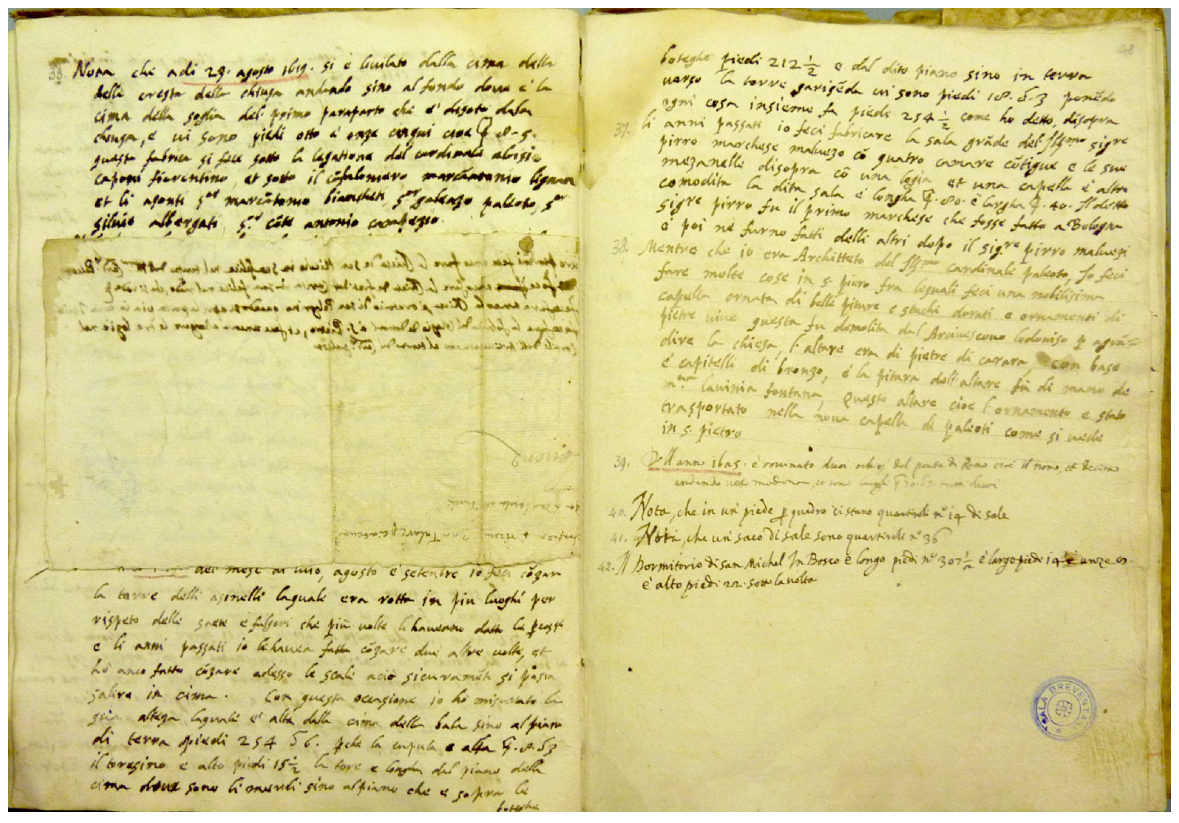

mento del dormitorio (in realtà il piano orizzontale dello strumento), che è pari a 31,6 piedi (approssimati a 32).

4) A verifica di questo calcolo viene utilizzato il triangolo BEA e il secondo teorema sui triangoli rettangoli per determinare la lunghezza del lato $A B$ (3 I 85 piedi).

5) Sempre attraverso lo stesso teorema, applicato al triangolo ACB, si determina la misura del lato BC (3I,5 piedi che Balbi approssima ancora a 32).

L'ultimo elaborato grafico qui presentato è il modello tridimensionale del lungo corridoio prodotto con il rilievo laser scanner FARO Focus [22], elaborato necessario per una verifica dei calcoli svolti circa tre secoli fa e, volendo, anche per una simulazione dell'effetto prospettico che si genera nel famoso vano (fig. 6).

Individuati i punti D e A su una retta orizzontale appartenente al piano della sezione longitudinale, è stata posizionata la torre a una distanza di 3183 piedi ( $1.209,54$ metri) e impostata un'altezza di 32 piedi. Gli angoli in D e A ottenuti corrispondono sul disegno CAD a $0^{\circ} 32^{\prime} 32^{\prime \prime}$ e $179^{\circ} 25^{\prime} 25^{\prime \prime}$; a queste piccole differenze di misura (circa mezzo primo

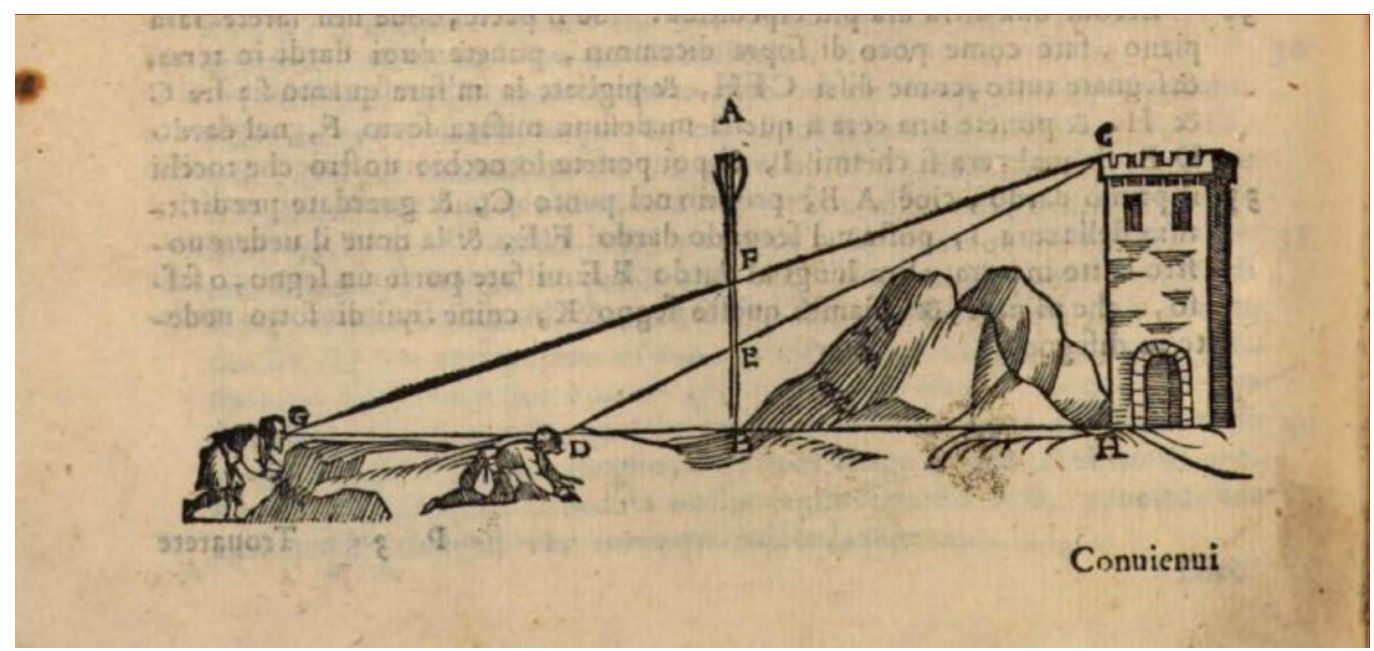

Fig. 8. Si veda a questo proposito il modo di misurare una torre di cul sia visibile solo la nel Ludi Matematici editi da Cosimo Bartol [Alberti I568, p. 230]. 
di grado rispetto alle cifre annotate da Balbi) deve essere riferita la notevole diversità tra i valori della distanza reciproca tra i due edifici che, nella realtà, ammonta a 1400 metri circa invece che 1200 (ben 526 piedi in più) [23]. Da ciò deriva necessariamente una differente altezza della torre rispetto al piano del dormitorio: 35,86 piedi invece di 32. Questa minima discrepanza nulla toglie allinteressante rilievo settecentesco e allo splendido elaborato che ne rappresenta i risultati e le procedure.

\section{La serliana e l'effetto prospettico (MI)}

L'attuale serliana fu dunque realizzata tra la fine del '500 e l'inizio del '600 probabilmente per ampliare l'illuminazione del vano e liberare l'asse visivo del lungo corridoio dalla colonnina della bifora originaria: in questo modo la torre degli Asinelli risulta perfettamente incorniciata secondo un principio certamente noto ai conoscitori della scienza della prospettiva, ma anche a coloro che vivevano nel monastero.

Fiorini, nel suo Diario (fig. 7), in cui sono annotate notizie personali, l'elenco dei suoi lavori e le misure di rilievo di varie chiese, riporta anche riflessioni sulla teoria dell'architettura attraverso i maggiori trattati da lui conosciuti. Questa parte di appunti costituisce una sorta di 'indice per argomenti' su temi progettuali e costruttivi, corredati da brevi note e rimandi (precisati con numero di libro, capitolo e pagina) ai testi diVitruvio, Leon Battista Alberti, Palladio, Sebastiano Serlio, Pietro Cataneo, Nicolò Tartaglia e altri [AABo, Archivio Arcivescovile di Bologna].

Lo scritto, la cui finalità è di raccogliere "alcune cose necessarie di sapere nelle occorentie" (c. 49r), si apre con la definizione dell'Architettura "scienza di molte discipline e amaestramenti" che, sull'esempio di Vitruvio, Fiorini elenca e commenta una a una: lettere, disegno, geometria e aritmetica. "Habia dissegno acio possia dipingere il suo concetto del opera che egli vora fabricare per mostrarlo ad altri quando è bisogno. Habia geometria per che essa è madre del dissegno per sapere pigliare in misura tutti li sitti e tirare le linee

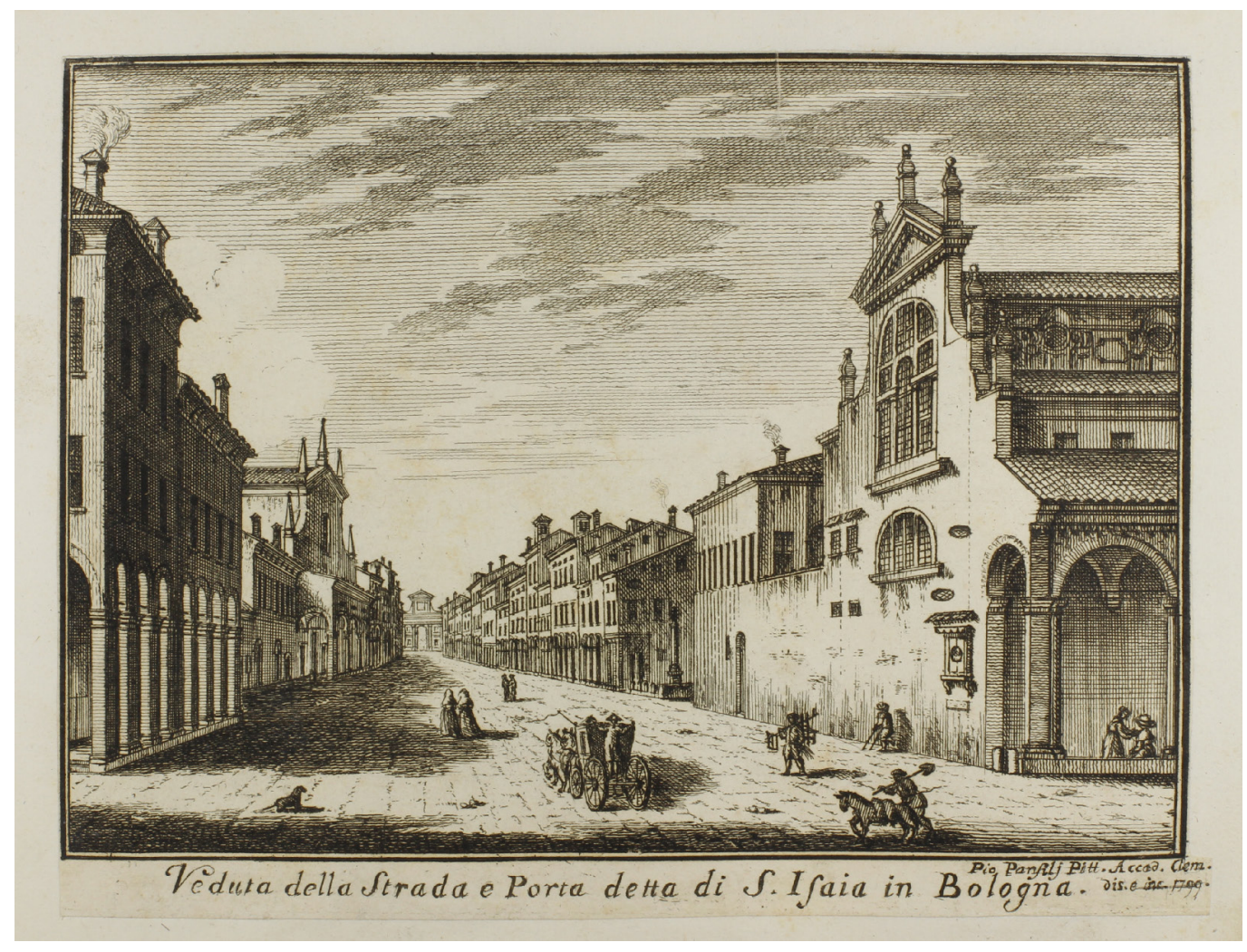


rette, le oblique e le circolari, è formare in dissegno qual si voglia fabrica o spaese così in pianta come anco nel alzato. Habia prospettiva per sapere mostrare indissegno qual si voglia cosa in scurtio pigliando alle volte la vista da uno lato è hora dal altro mostrado la forma di quella cosa istessa, ma di vista diferente. Habia aritmetica per potere trovare li conti delle misure delle fabriche, è delle spese da farsi e delle fatte e trovare ancora la proporzione de tutte le cose" (c. 49r).

La sua formazione da pittore [Balboni 2019, p. 52] e la sua documentata esperienza di rilevatore lasciano presuppore la conoscenza e il possesso dei principi della prospettiva pratica e, in particolare, delle condizioni di intersezione della piramide visiva con il quadro [24]. A questo proposito è noto come, al crescere della distanza del punto di vista dal quadro, l'altezza $\mathrm{H}$ di un soggetto aumenta in ragione dell'angolo sotteso (fig. 8). Nel corridoio di san Michele in Bosco il fenomeno diviene percettivamente evidente [25] solo

Fig. 10. Dettaglio della serliana progettata dal Fiorini: alle due aperture rettangolari laterali sono sovrapposte due specchiature in muratura. La finestra è sormontata da un grande arco a tutto sesto tripartito sinistra l'ortofoto tratta dal rilievo laser scanner a destra la restituzione a destra la restituzion grafica M. Incerti).
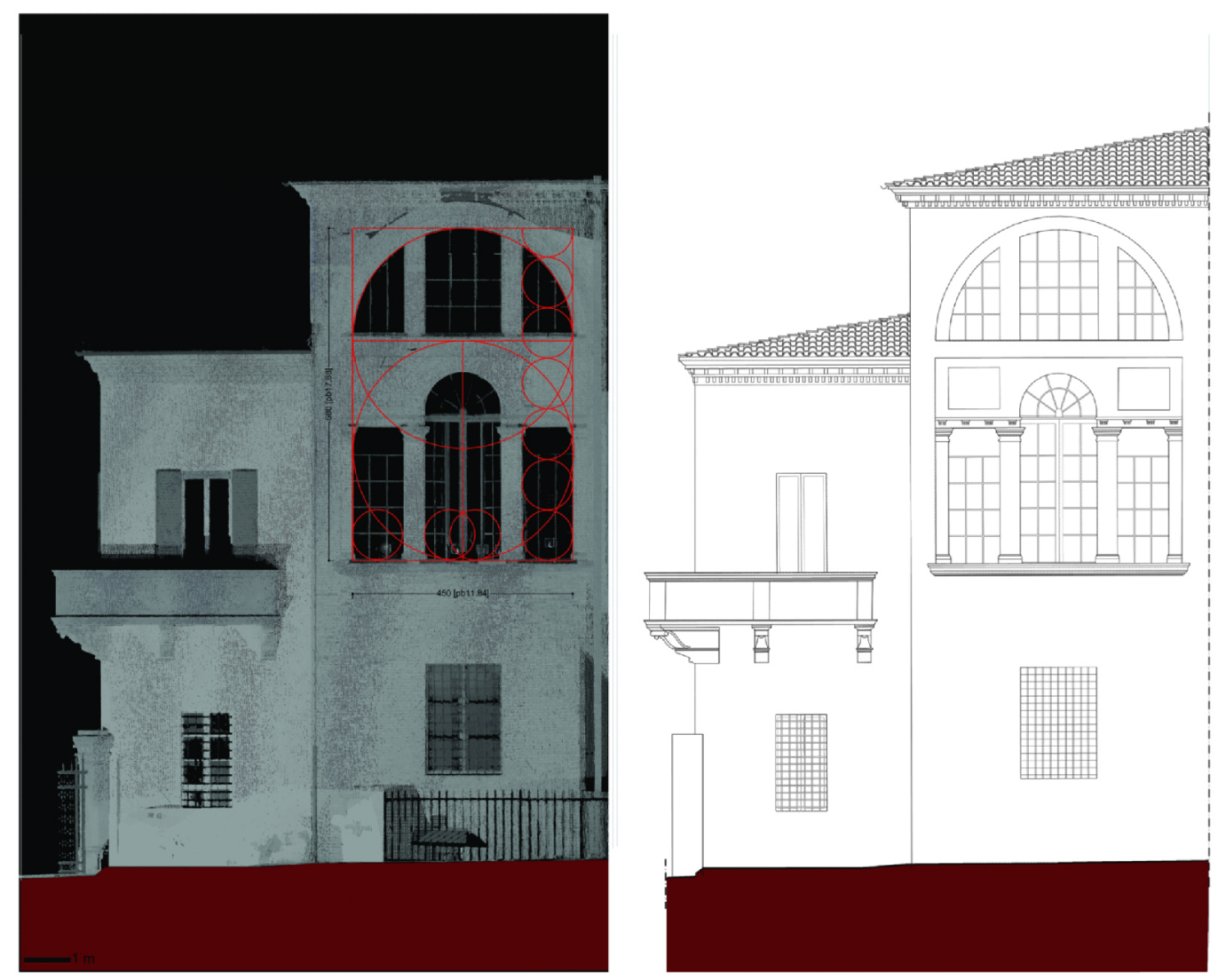

quando l'intera finestra entra nel cono visivo: la cornice rettangolare, 'finestra albertiana', costituisce infatti l'elemento di paragone che fa aumentare l'altezza della torre al crescere della distanza dell'osservatore. Il fenomeno, forse meno spettacolare di quanto oggi appare, doveva essere comunque già noto nella fase in cui era presente la bifora visto che la colonnina centrale poteva agevolmente svolgere la funzione di 'dardo' albertiano.

In conclusione, questa grande serliana (figg. 9, 10) fu, molto probabilmente, disegnata dall'architetto Pietro Fiorini e il sorprendente effetto visivo, anche oggi fruibile, venne dunque progettato da questo architetto bolognese ancora oggi non adeguatamente studiato. 
Fig. I I. II lungo corridoio del dormitorio (vista dando le spalle alla città)

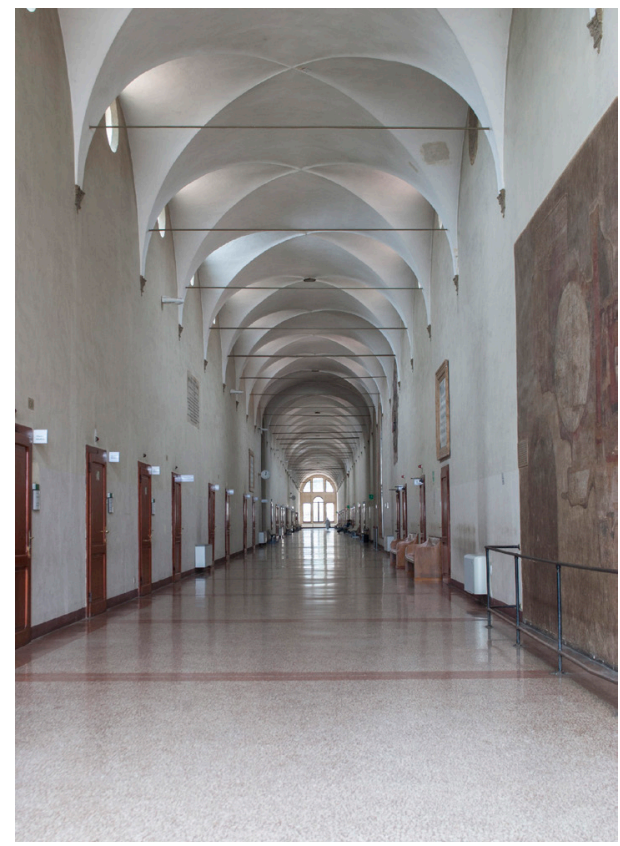

\section{Note}

[I] S. Michele in Bosco 177/2349, che si riferisce ai lavori dal I579 al 1616. Inoltre, S. Michele in Bosco 196/5 I92 edito da Minucci 1966, pp. 169 e segg. Gli abati stanno alle pp. 192-193.

[2] Zucchini 1954-1955 e ora Balboni 2019.I lavori in S. Michele in Bosco stanno alle pp. 63, 64.

[3] Questo lavoro fu apparentemente ripetuto più oltre con le stesse parole, in realtà l'appunto si riferiva a momenti diversi e successivi del rifacimento degli edifici prospicienti il chiostro grande.

[4] Minucci 1966, p. 192. Nel 1596 lo dice vescovo di Castro. Don Placido Fava fu abate a S. Michele in Bosco anche nel 1587. Ibidem, p. 193

[5] Balboni 2019, p. 63; Minucci 1966, p. 193, anno 1602.

[6] Minucci 1966, p. 193. Lo fu anche per altri anni, ma i pagamenti al Fiorini ci riportano al I 606.

[7] Ibidem lo segnala all'anno 1608 e di nuovo il Cantoni al I6। I.

[8] Ibidem.

[9] S. Michele in Bosco 177/2349, c. 43

[10] Ibidem, c. 102v e segg.

[ I I] S. Michele in Bosco 177/2349, c. I I I e segg.

[12] Ibidem, c. I 16 e segg. e nello specifico a c. II7v.

[13] Da ultima, Balboni 2019, pp. 54-55, sia per la cappella Poggi in S. Giacomo sia per il chiostro ottagonale.

[I4] Fratello del pontefice Urbano VIII, morì nel corso d'una missione a Bologna il 26 febbraio I 630. DBI, I 964, 6.

[15] DBI 1985, 31. Nacque a Bologna nel 1599 e morì nella stessa città nel 1647.

[16] Frati 1889, col. II 8 e Medici 1853, pp. 865-889 con ritratto.

[ I 7] Si tratta della Cena di san Gregorio Magno, della tavola di Gesù in casa di Marta e Maria, e di un terzo dipinto andato perduto, Abramo nella valle di Mambre. L'incarico venne regolato da un contratto sottoscritto il 2 febbraio 1539.

[18] II portico di accesso alla chiesa presenta tre arcate, una delle quali fu poi demolita per realizzare la cappella di Santa Francesca Romana. Sulle vicende cinquecentesche della chiesa si veda Foschi 2020.

[19] La firma è in basso sul simbolo del nord.

[20] Anche sulla base di un confronto con delle misure del rilievo laser scanner è necessario che il lato AD sia orizzontale.

[2 I] La verifica con strumento posizionato a una medesima altezza dal pavimento (AD non orizzontale) ha dato luogo a valori lontani da quanto dichiarato nel disegno. 
[22] Si ringrazia l'ing. Piero Lusuardi (20|4).

[23] La misura è stata presa su Google Earth con lo strumento righello.

[24] Ci si riferisce ai principi della perspectiva, editi in età medioevale in opere intitolate indifferentemente Perspectiva, De aspectibus o De visu, utilizzati nelle procedure di rilievo mediante triangoli simili e aste graduate. Cfr.Vagnetti 1979, Vescovini Federici 1998.

[25] II fenomeno è stato studiato dal punto di vista percettivo in Costa 2017.

\section{Riferimenti bibliografici}

AA.V. (1997). DBI Dizionario Biografico degli Italiani, Roma: Istituto Treccani.

Alberti L. B. (1568). Opuscoli morali.Venetia: Appresso Francesco Franceschi Sanese.

Balboni V. (2019). «Si è fatto tanto avanti che ha uguagliato li altri» Architetture e scritti di Pietro Fiorini architetto bolognese (I539- 1629). In Quaderni dell'stituto di Storia dell'Architettura, 70, pp. 39-66.

Costa M., Bonetti L. (20 I7). Linear Perspective and Framing in the Vista Paradox. In Perception, 46, I I, pp. I 245- I 268.

Foschi P. (2020). Incroci padani. Biagio Rossetti, Pellegrino Prisciani e Bologna. In Schifanoia 58-59, 2020, pp. 55-66.

Foschi P. et al. (2017). Monasteri benedettini nella diocesi di Bologna (secoli VII-XV). Bologna: Bononia University Press.

Frati L. ( 889$)$. Opere della bibliografia bolognese, 2. Bologna: Zanichelli.

Martini A. (1883). Manuale di metrologia. Torino: Loescher.

Medici M. (I853). Elogio di Paolo Battista Balbi. In Memorie dell'Accademia delle Scienze dell'Istituto di Bologna, IV. Bologna: Tipografia a S.Tommaso d'Aquino.

Minucci P. I. (1966). Aspetti inediti di storia tratti dai regesti d'archivio. Roversi Giancarlo. In San Michele in Bosco. Bologna. Bologna: Poligrafici ll Resto del Carlino.

Repishti F. (20 I I). «Et si sa che non è architetto aprobato se non nel modo che fanno i principi». Gli esordi di Pellegrino Tibaldi architetto. In F. Ceccarelli, D. Lenzi (a cura di). Domenico e Pellegrino Tibaldi. Architettura e arte a Bologna nel secondo Cinquecento. Venezia: Marsilio.

Vagnetti L. (1979). De naturali et artificiali perspectiva: bibliografia ragionata delle fonti teoriche e delle ricerche di storia della prospettiva: contributo alla formazione della conoscenza di un'idea razionale, nei suoi sviluppi da Euclide a Gaspard Monge. Firenze: L.E.F.

Vescovini Federici G. (1998). Prospettiva (voce). In Enciclopedia dell'arte medievale; < https://www.treccani.it/enciclopedia/prospettiva_\%28Enciclopedia-dell\%27-Arte-Medievale\%29/> (consultato il 21 gennaio 2021).

Zucchini G. (1954-55). Un manoscritto autografo dell'architetto Pietro Fiorini. In L'Archiginnasio, XLIX-L, pp. 60-99.

\section{Archivi}

ASBo, Archivio di Stato di Bologna, Demaniale, S. Michele in Bosco 177/2349.

ASBo, Archivio di Stato di Bologna, Demaniale, S. Michele in Bosco 196/5192.

ASBo, Periti agrimensori.

BCABo, Biblioteca dell'Archiginnasio di Bologna, Gabinetto Disegni e Stampe.

AABo, Archivio Arcivescovile di Bologna, Fondo Breventani G (I) VIII n I, Diario di Pietro Fiorini.

\section{Autori}

Manuela Incerti, Università degli Studi di Ferrara, manuela.incerti@unife.it

Paola Foschi, Deputazione di Storia Patria per le Province di Romagna, pfoschi@hotmail.it

Per citare questo capitolo: Incerti Manuela, Foschi Paola (2021). Pietro Fiorini e la prospettiva su Bologna/Pietro Fiorini and the perspective on Bologna. In Arena A., Arena M., Mediati D., Raffa P. (a cura di). Connettere. Un disegno per annodare e tessere. Linguaggi Distanze Tecnologie. Atti del $42^{\circ}$ Convegno Internazionale dei Docenti delle Discipline della Rappresentazione/Connecting. Drawing for weaving relationship. Languages Distances Technologies. Proceedings of the $42^{\text {th }}$ International Conference of Representation Disciplines Teachers. Milano: FrancoAngeli, pp. 783-804. 


\title{
Pietro Fiorini and the Perspective on Bologna
}

\author{
Manuela Incerti
}

Paola Foschi

\section{Abstract}

A singular effect occurs in the long corridor to the ancient dormitory of Bologna's former monastery, San Michele in Bosco. It is known (informally) as telescope: moving away from the serlian window that opens onto the city of Bologna, the central rectangle of the window perfectly frames the Asinelli Tower, which thus appears to increase in size. Through historical document research and the tools of drawing, we seek to investigate this phenomenon to clarify its origin and possible reasons.

\section{Keywords}

Pietro Fiorini, San Michele in Bosco, perspective, survey, distance.

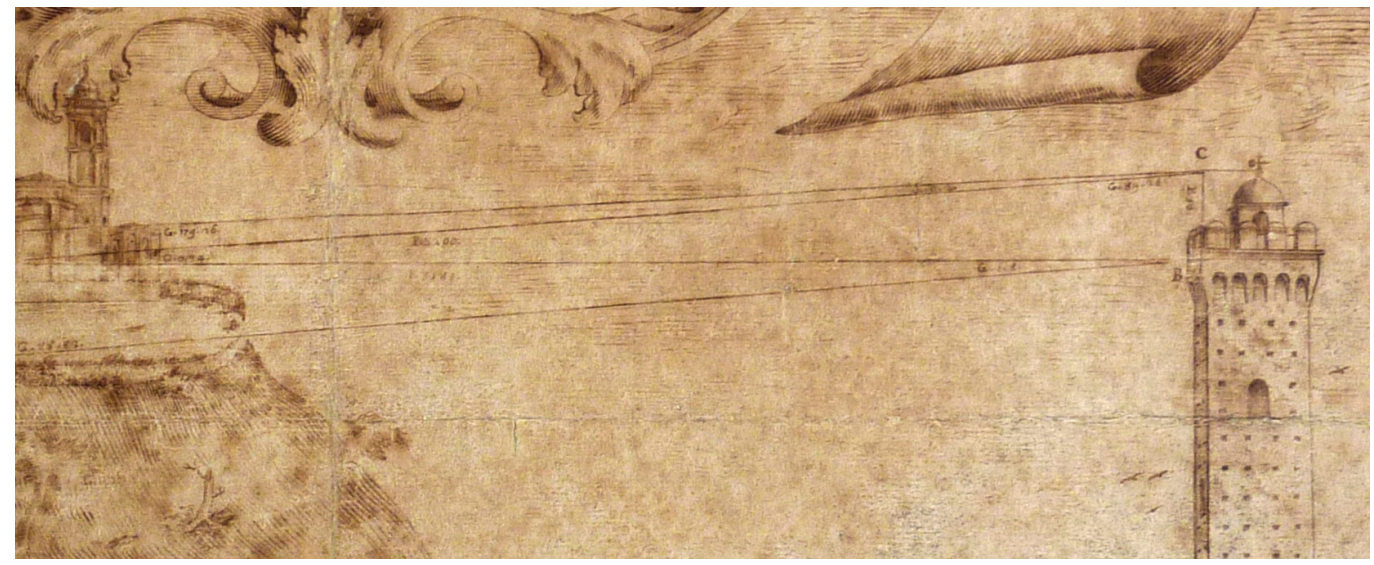




\section{The architect Pietro Fiorini (I539-I629) in the S. Michele in Bosco monastery (PF)}

The works of the late sixteenth century, carried out by the Bolognese architect Pietro Fiorini, have given the monastery its current general appearance. They also resulted in the construction of the large arm of the dormitory with the serlian window that frames the top of the Asinelli Tower.The monastery's books attest to his various interventions in the large Olivetan monastic complex.

The optical phenomenon called "telescope", which occurs in the long dormitory of S. Michele in Bosco when observing the Asinelli tower through the serlian window (fig. I), introduces the broader theme of the works carried out by the architect Pietro Fiorini [DBI 1997, pp. 205-206] for the Bolognese Olivetans between I580s and the end of the I620s [Foschi et al. 20 I7, pp. I8I189]. In this examination, we are helped by both the monastery's books [I] and the biographical notes of the architect himself, now published and commented [2].

His notes list a substantial block of works with no explicit chronological indication but accompanied by the name of the father abbot who commissioned them. Fiorini first built the large cloister with the central cistern [3], the main passage (entrance), the main stairs and the new guest quarters. He also arranged for the infirmary and built the stable of the father abbot of the time, who was don Placido Fava ( 1587; later elected prior general of the Olivetan congregation and bishop of Naples) [4], as well as the stables of the monastery at the time of father abbot don Lorenzo Panara (I600) and then of don Angelo Maria Cantoni ( $160 \mathrm{I}$ ). The octagonal cloister was commissioned by father abbot don Onorato (Veli) in I602 [5], and by F. Angelo Maria Cantoni, in I 605 [6].

At the request of father abbot Greco (Pier Paolo da Galatina, 1608) [7], who was superseded in I6 I I by F. don Angelo Maria Cantoni, he built the new rooms under the novitiate, as well as the novitiate itself. F. Fava also commissioned the factory adjacent to the dormitory with the loggias, the courtyard that served as a woodshed and the upstairs rooms used as guest quarters. The same abbot also had him complete the cellar, the kitchen, the oven and repair the bell tower that had been damaged by lightning. This series of works must have been distributed from 1587, the first administration of the Fava, to I599, the last [8].

The books of the monastery record a payment made to Fiorini on January 28, 1589 of 10 Florentine scudi for "having drawn up the plan of our monastery", equivalent to 4 I lire of bolognini [9]. In I603, the payment records for the octagonal cloister begin. Also known as the "cloister of the door", it was commissioned by F. Onorato Veli in his first year of administration 1602 [I0]. Fiorini received 26 lire and 2 soldi "for the loving kindness of the commission for the very

Fig. I. View of the Asinell Tower from the corridor of the monastery (photo by $M$. Incerti).

Fig. 2. Refectory of San Michele in Bosco, frescoes with stories of the Apocalypse and views of the Olivetan views of the Olivetan monasteries, panel of the Bolognese monastery and detail.
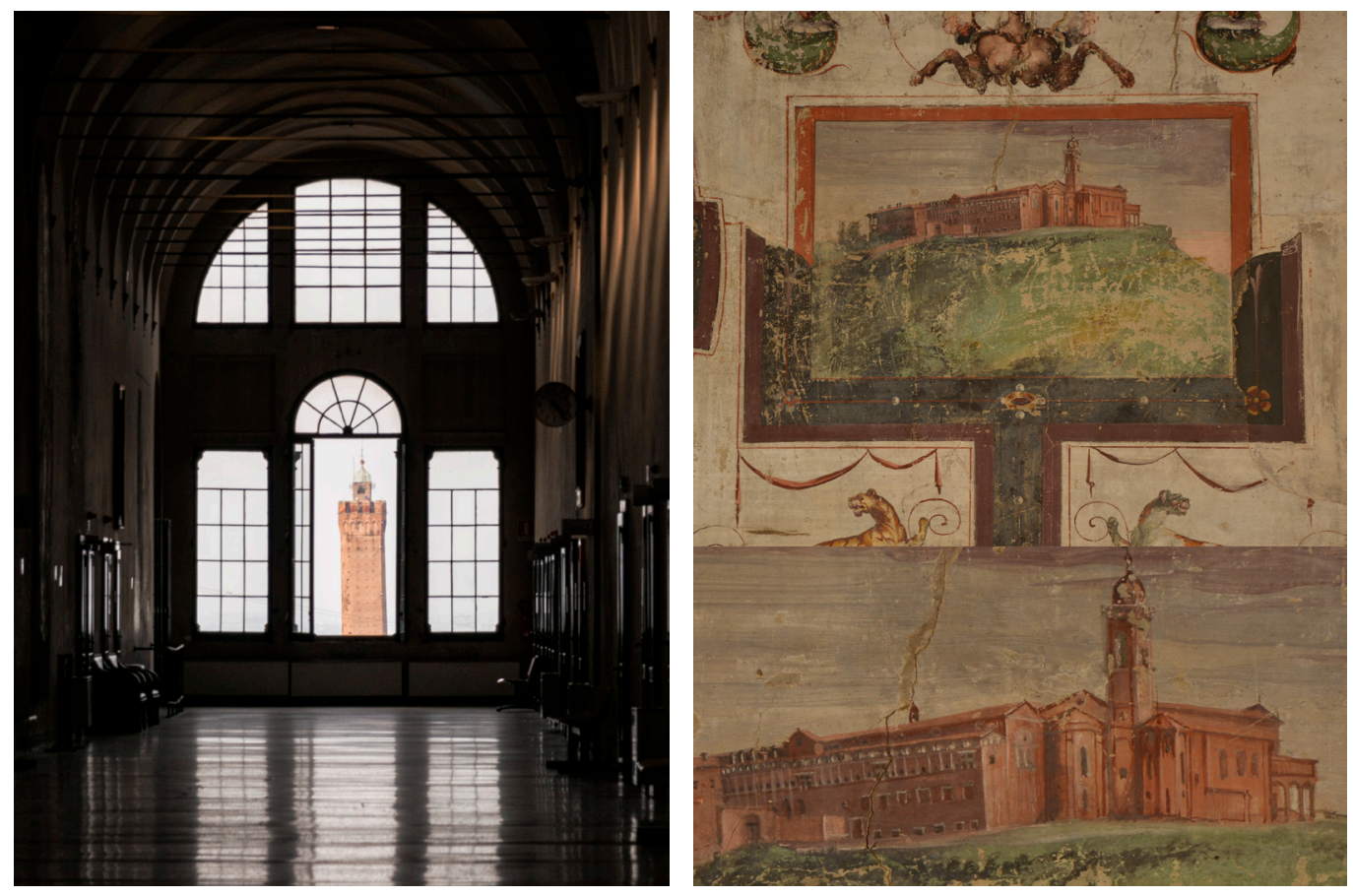
reverend father abbot". He was not paid for manual work or supplies of materials like the other craftsmen, he was paid for his design work. From 1605, the payments for the paintings in the octagonal cloister begin [I I], as well as those for the construction of the courtyard, the cistern and an addition to the dormitory. In that period [I 2], Pietro Fiorini was paid in two instalments: 57 lire "for kindness" and 2 lire 2 soldi for reparation works. Later, in 1612, he was paid 37 lire soldi 6 "out of courtesy" for the works carried out in the new dormitory for the Capuchins. The last work mentioned is that of the new novitiate in 1613. In this case 30 lire, 8 soldi and 4 denari were also paid "for kindness".

So Fiorini worked on both the dormitory in 1587 and on the new dormitory towards the west in 1606, that is towards the nearby Capuchin convent (now replaced byVilla Revedin). The serlian window must therefore have been his idea, also considering that various normal and Corinthian architraves, and Corinthian capitals were paid to the stonecutters in the construction of the factory of the octagonal cloister and the dormitory.

Fiorini's predilection for the Serliana, both as a window and as a characterizing order of architecture, has already been noted [13] and linked to the style of Domenico Tibaldi, whose ancestors worked in the monastery during the previous century [Repishti 201 I, pp. I29-14I]. In fact, the archivist of S. Michele in Bosco in 175 I [Minucci 1966, p. I7I] specified that the oldest dormitory had been built in 1438. However, two other arms had been built, one in I587, including the lower middle cloister, the other in 1606, including the stables, courtyard and cistern.

The serlian window appears in a drawing dated 5 March 1630 [Cartella Gozzadini 27, n. I4I], which immortalizes the procession of Bolognese military and civil companies engaged in accompanying the coffin of the general of Santa Madre Chiesa don Carlo Barberini [14] from the monastery to the church of S. Michele in Bosco. Its author is Floriano dal Buono, an engraver and skilled at drawing, but also a painter and sculptor [15].

To these testimonies one must add the bird's-eye drawing of the monastery in I583, with the surrounding land possessions belonging to the register of the possessions outlined for the Olivetans by the surveyor Alfonso Nelli, operating from 1556 to 1628 [Periti agrimensori, indice]. One must also consider the drawing and relative calculation of the relationship between the height of the Asinelli Tower and the dormitory of S. Michele in Bosco executed in 1722 by Paolo Battista Balbi (I693-1772) [16], illustrious physicist and anatomist, aggregate and president of the Academy of Sciences and the Benedictine Academy.

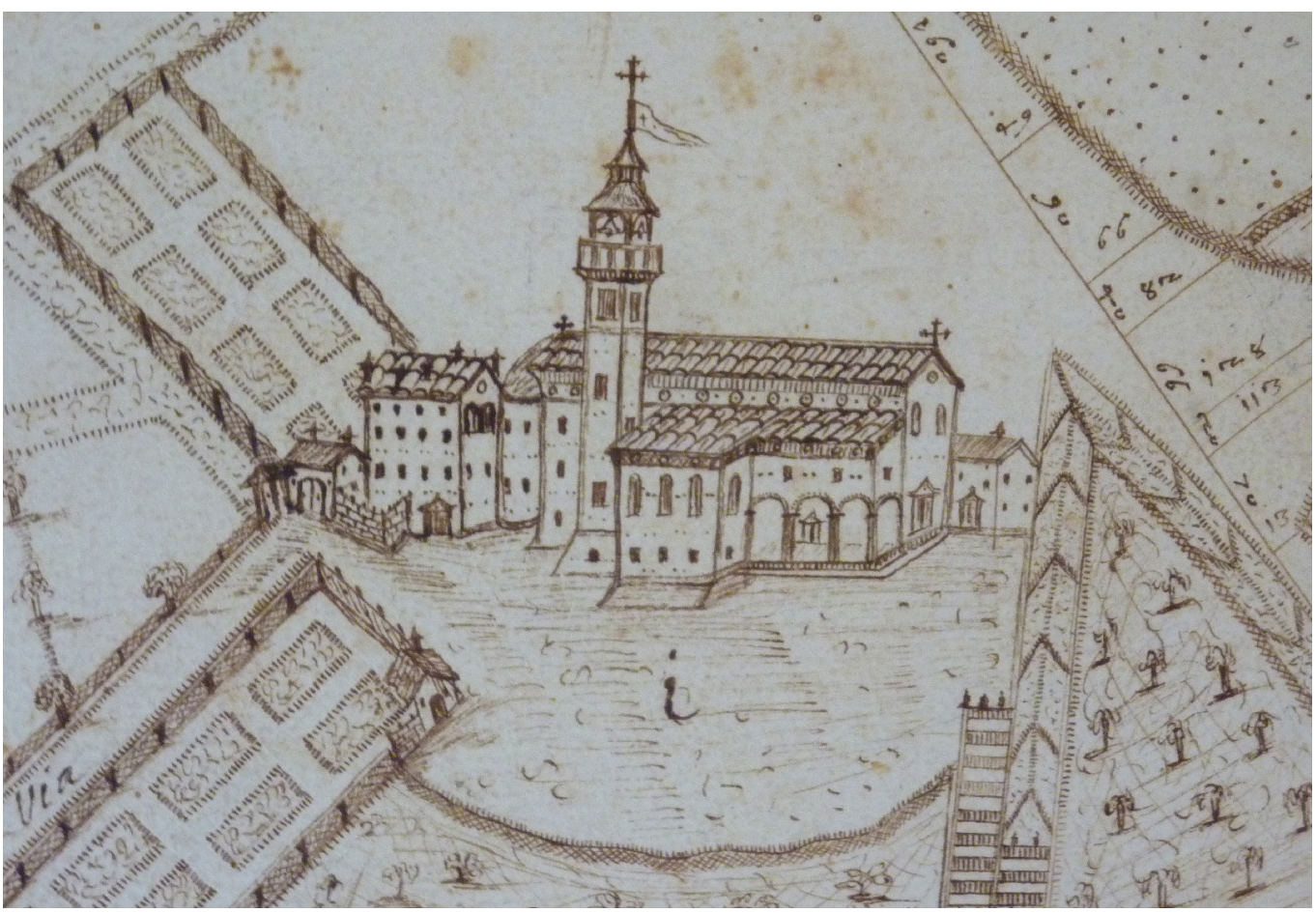




\section{The serlian window and the Asinelli Tower (MI)}

The oldest known representation of the west side of the monastery, the side occupied by the monks' dormitory, dates back to the years I539-40 and the assignment that Vasari received to decorate the great hall of the monks' refectory (fig. 2). As the artist recounts in his Vite, three large canvases on the theme of fraternal charity and hospitality were commissioned to be placed in front of the entrance door of this important space [17]. The decorative program also included a grotesque frieze with scenes from the Apocalypse and views of the Olivetan monasteries of Italy, which was created by three of his collaborators: Cristoforo Gherardi, known as the Doceno, Giovan Battista Cungi and Stefano Veltroni.This sixteenth-century image of the monastery gives us a representation of the long dormitory, flanked by the body of the factory building and the cells with the loggia (which today no longer exist). The window of the long corridor overlooking Bologna is unquestionably a mullioned window with an oculus [18].

The same mullioned window appears in a second image: an ink drawing on paper preserved in the Bologna State Archives (fig. 3) previously cited. In this Cabreo delle Mappe e Piante de Beni, dated I583, the dormitory is more stylized and less visible but always ends with a mullioned window with an oculus.

The characteristic serlian window that today distinguishes the view over Bologna appears in the 1630 view indicated above (fig. 4) and in the refined drawing on paper dated September 17| 4, with which Paolo Battista Balbi [19] illustrates the topographical calculations made to estimate the height of the Asinelli Tower with respect to the floor of the dormitory of San Michele in Bosco (fig. 5). At the top, on the sides of the title of the drawing, there are two title blocks: on the left the segments considered are listed (Tab. I), while on the right there is a summary of the topographic operations and the execution of the calculations (Tab. 2). According to the author of this survey, the difference in height between the two elements is 32 Bolognese feet (ie 12.16 meters [Martini 1883, p. 92]), while the distance is 3183 feet (ie 1209 meters).

Fig. 4. Floriano dal Buono 1630. Ordine tenuto nel trasportar fuori del monastero de R.P. di S. Michel in Bosco il corpo del Ec.mo Sig.r Don Carlo Barberini Generale di S.a M.e Chiesa et portarlo nella Chiesa deglidett Padri.ll diV di Marzo $M D C X X X(B C A B O$ $M D C X X X(B C A B O$ Gabinetto Disegni e Stampe, cart. Gozzadini 27, n. 141)

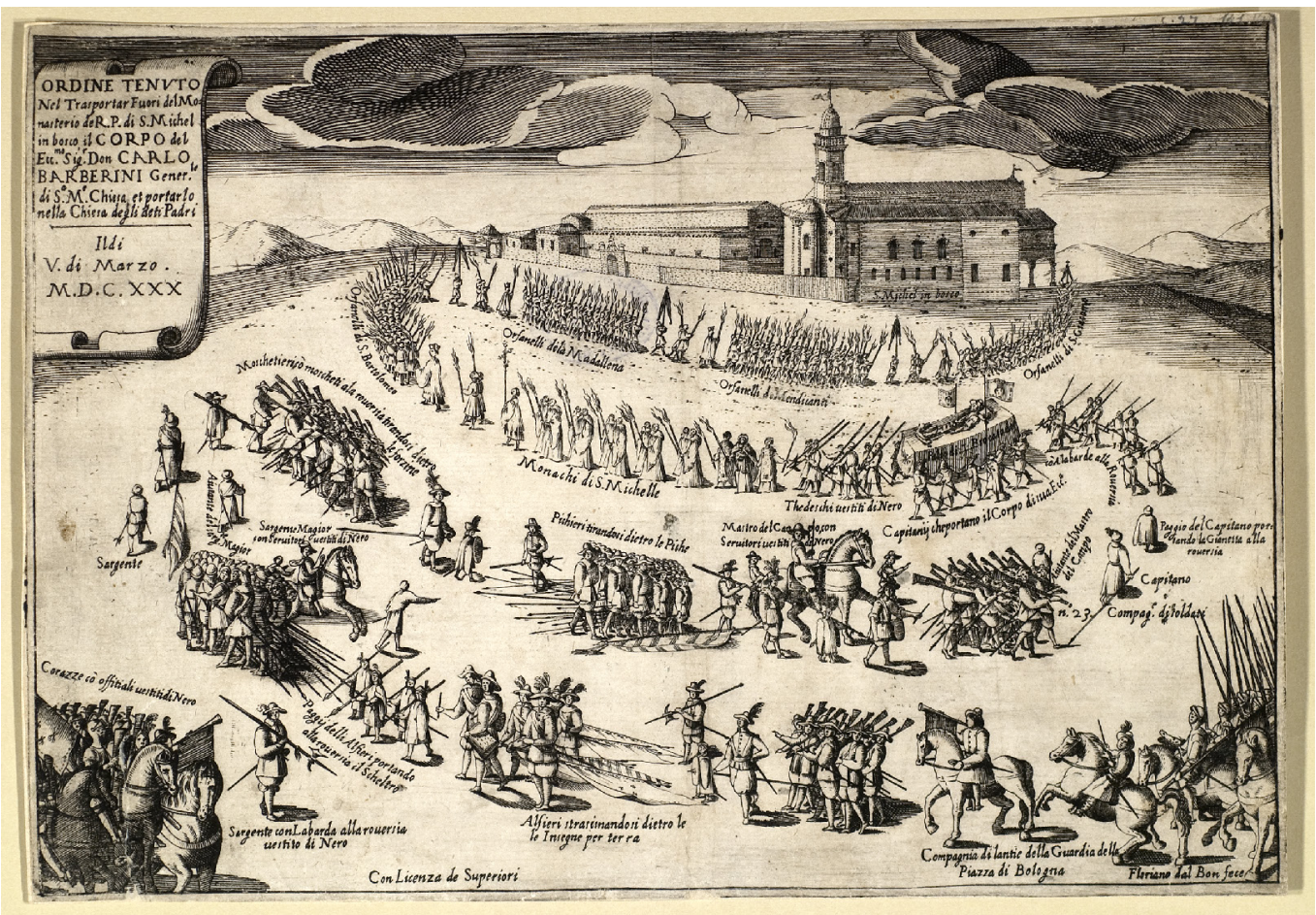


Tab. I Segments of topographical measurements

$\mathrm{CH}$ Height of the Asinelli tower

CB Elevation of the tower above the dormitory floor CB.

AF Altitude of the hill of San Michele in Bosco

AK Part of the dorm whose length is 422 feet

AE Distance from the front of the dorm to station $E$, east to the meadows, 63 feet

TO Distance from the front of the dormitory to station D in it made 200 feet

$B C$ Distance from the front of the dorm to the top of the tower

$A B$ Distance Tower to the front of the dorm

\begin{tabular}{|c|c|c|c|}
\hline & & & Notes by the author \\
\hline ADC obtuse triangle solution & & & $\begin{array}{l}\text { The application of the theorem of sines (or } \\
\text { Euler's): In any triangle the ratio between the } \\
\text { measure of one side and the sine of the op- } \\
\text { posite angle is constant }\end{array}$ \\
\hline Sine of the angle ACD & $0^{\circ} 32^{\prime}$ & 93083 & From the trigonometric tables \\
\hline Side AD Bolognese feet & & 200 & \\
\hline The product of these numbers & & $|8.6| 6.560$ & \\
\hline Sine of the angle ACD & $0^{\circ} 02^{\prime}$ & 5.818 & From the trigonometric tables \\
\hline AC length quotient in feet & & 3.200 & \\
\hline Right triangle solution $B A C$ & & & $\begin{array}{l}\text { First theorem on right triangles: the measure } \\
\text { of a cathetus is equal to the product of the } \\
\text { measure of the hypotenuse by the sine of the } \\
\text { opposite angle }\end{array}$ \\
\hline Sine of the angle BAC & $0^{\circ} 34^{\prime}$ & 98.900 & From the trigonometric tables \\
\hline Side AC Bolognese feet & & 3.200 & \\
\hline The product of these numbers & & 316.480 .000 & \\
\hline Divider radius & & 10.000 .000 & \\
\hline $\mathrm{BC}$ length quotient in feet & & 31,6 & \\
\hline Right triangle solution BEA & & & $\begin{array}{l}\text { Second theorem on right-angled triangles: the } \\
\text { measurement of one side is equal to that of } \\
\text { the other side by the tangent of the opposite } \\
\text { angle }\end{array}$ \\
\hline Tangent angle AEB & $88^{\circ} 52^{\prime \prime}$ & 505.485 .059 & From the trigonometric tables \\
\hline Side AE Bolognese feet & & 63 & \\
\hline The product of these numbers & & 31.845 .558 .717 & \\
\hline Divider radius & & 10.000 .000 & \\
\hline$A B$ length quotient in feet & & 3185 & \\
\hline Right triangle solution $A C B$ & & & $\begin{array}{l}\text { the measure of one cathetus is equal to that } \\
\text { of the other cathetus for the tangent of the } \\
\text { opposite angle }\end{array}$ \\
\hline Tangent angle BAC & $0^{\circ} 34^{\prime}$ & 98.905 & from the trigonometric tables \\
\hline Side AB Bolognese feet & & 3185 & \\
\hline The product of these numbers & & 315.012 .425 & \\
\hline Divider radius & & 10.000 .000 & \\
\hline $\mathrm{BC}$ length quotient in feet & & 32 & \\
\hline
\end{tabular}


Fig. 5. Paolo Battista Balbi, 17|4.Typus ostendens praxim adhibitam in excessu quaerendo Turris Asinellae supra pavimentum dormitorij monachorum divi Michaelis in Busco (BCABo, Gabinetto dei Disegni Stampe, Cart. I, 3) (graphic elaboration M. Incerti).

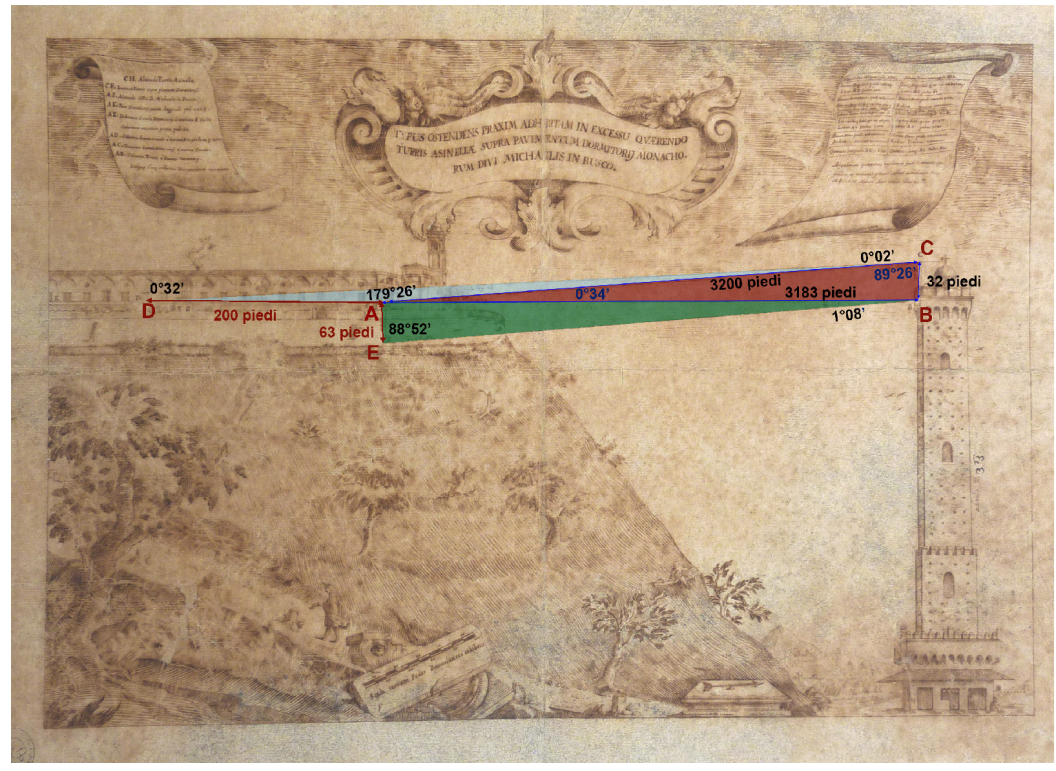

In the survey Balbi uses three triangles: one obtuse and two right angle triangles. The sequence of operations, performed with theodolite, can be summarized as follows:

I) Given the segment AD equal to 200 feet, the angles formed by sighting the top of the tower indicated by the letter $C$ [20] from points $A$ and $D$ are measured. The height of the instrument in these station points had to be at least equal to that of the sill of the serlian window (about I meter high) or, more likely, slightly higher to be able to easily use the measuring instrument. The laser scanner survey certifies that, due to the slope of the floor, the height of 1.5 meters in A corresponds to 1.19 meters in $D$ [2 I].

2) Measuring the angle of $0^{\circ} 32^{\prime}$ in $D$ and the angle of $179^{\circ} 26^{\prime}$ in $A$, the third angle in $C$ (equal to $0^{\circ} 02^{\prime}$ ) is obtained by difference. By applying the sine theorem, it is thus possible to find the length of the side $A C$ : given that $A D$ is equal to 200 feet, we obtain $A C$ equal to 3200 feet.

3) Considering the right angle triangle $B A C$ (of which we now know the hypotenuse equal to 3200 feet) we measure the angle in $A\left(0^{\circ} 34^{\prime}\right)$. Through the first theorem on right-angle
Fig. 6. Orthophoto processed by the registration of the lase scanner survey (145 scans, Scene 2020, M. Incerti). The angles were calculated with CAD software and, given the dimensions of the triangles considered (1 400 by 14 meters (1400 by 14 meter approximately), the
drawing is not graphically adequate for a canonical page of a book

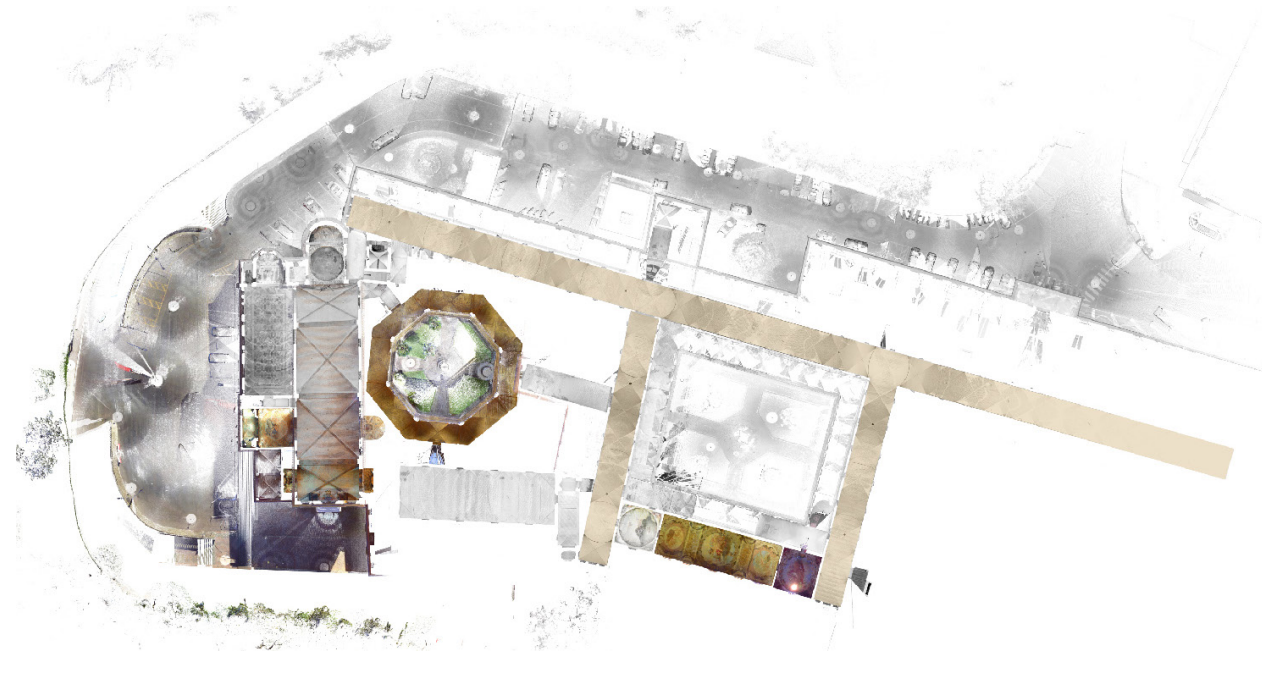


Fig. 7. Fiorini notes that between July and September 1619, he repaired the Asinelli Tower. On this occasion, he measured its height from the "cima helo rom the "cima della bala sino al piano The in inches high, the toresino is 15 feet (P. Fiorini, Diary, $\mathrm{AABO}$ ).

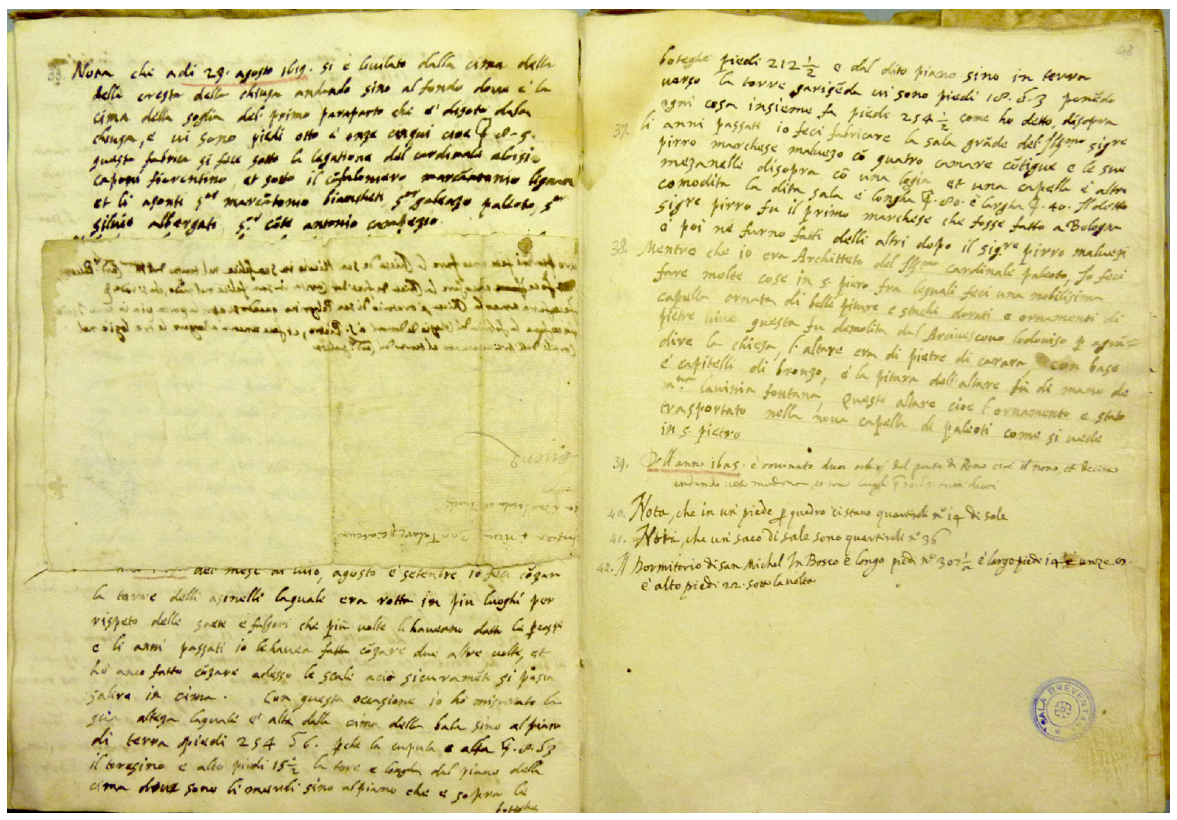

triangles, we determine the length of the side $\mathrm{BC}$, that is the height of the tower that raises the level of the dormitory floor (the horizontal plane of the instrument), which is equal to 31.6 feet (approximated to 32)

4) To verify this calculation, the triangle BEA and the second theorem on right-angle triangles are used to determine the length of the side $A B$ (3 I 85 feet).

5) Again, using the same theorem applied to the triangle $A C B$, the measurement of the side $\mathrm{BC}$ is determined (3I.5 feet, which Balbi still approximates to 32).

The last graphic elaboration here presented is the three-dimensional model of the long corridor produced with the laser scanner FARO Focus survey [22]. The elaboration is necessary for a verification of the calculations carried out three centuries ago and, if desired, also for a simulation of the perspective effect that it is generated in the famous room (fig. 6). Having identified points $D$ and $A$ on a horizontal line belonging to the plane of the longitudinal section, the tower was positioned at a distance of 3183 feet (I,209.54 meters) and set at a height of 32 feet. The angles in $D$ and $A$ obtained correspond on the CAD drawing to

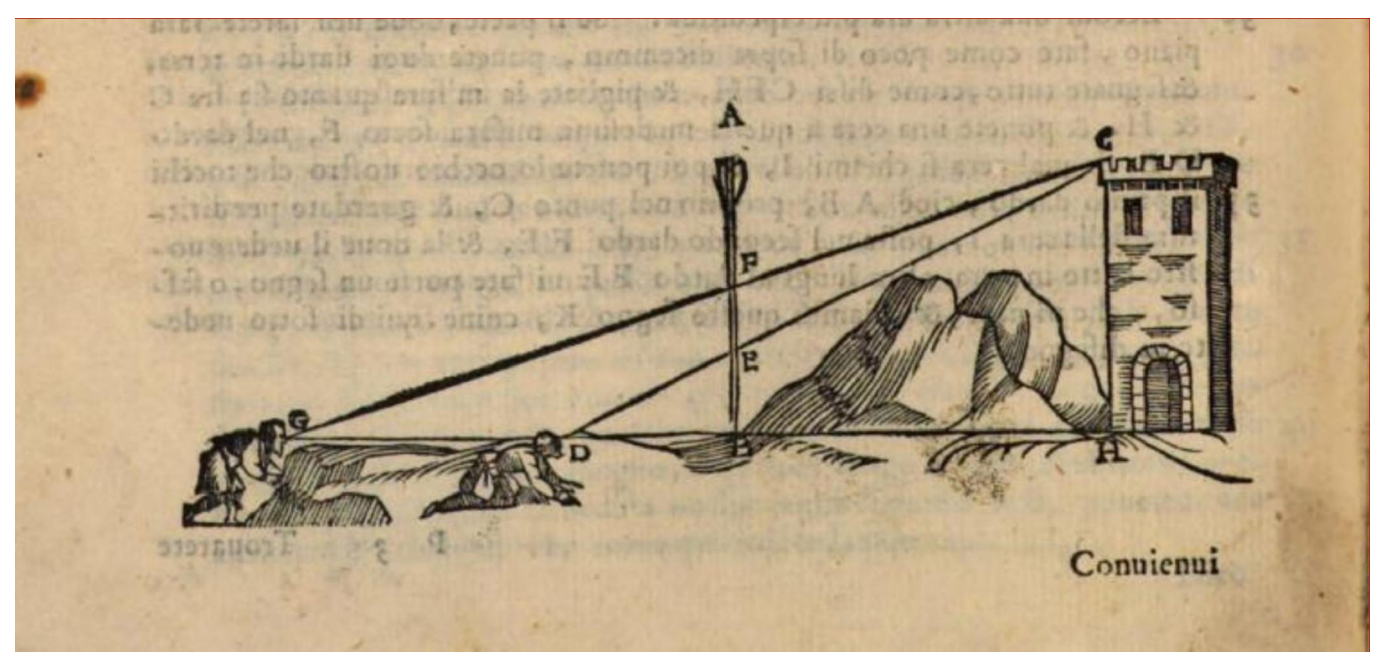

Fig 8. How to measure a tower of which only the top is visible and not the base in the Ludi Matematici, published by Cosimo Bartoli (Alberti 1568, p. 230). 
$0^{\circ} 32^{\prime} 32^{\prime \prime}$ and $179^{\circ} 25^{\prime} 25^{\prime \prime}$. The considerable difference between the values of the mutual distance between the two buildings must be due to these small differences in measurement (about half a minute of arc compared to the figures noted by Balbi) and amounts to about 1400 meters instead of I 200 (526 feet more) [23]. From this, a different height of the tower with respect to the dormitory floor is necessarily derived: 35.86 feet instead of 32 . This minimal discrepancy does not detract from the interesting eighteenth-century relief and the splendid elaborate that represents the results and procedures.

\section{The serlian window and the perspective effect (MI)}

The current serlian window was therefore built between the end of the 1500s and the beginning of the 1600s, probably to expand the lighting of the room and free the visual axis of the long corridor from the column of the original mullioned window. In this way, the Asinelli Tower it is perfectly framed according to a principle certainly known to connoisseurs of the science of perspective, but also to those who lived in the monastery.

Fiorini, in his Diario (fig. 7), in which personal information, the list of his works and the survey measurements of various churches are noted, also reports reflections on the theory of architecture through the major treatises known to him. This part of his Diario constitutes a sort of index for topics on design and construction themes, accompanied by short notes and references (with book number, chapter and page) to the texts of Vitruvius, Leon Battista Alberti, Palladio, Sebastiano Serlio, Pietro Cataneo, Nicolò Tartaglia and others [AABo, Archiepiscopal Archive of Bologna].

The paper, whose purpose was to collect "some things necessary to know when needed" (c. 49r), begins with the definition of Architecture, "science of many disciplines and teachings". Following the example of Vitruvius, Fiorini lists and comments each one: literature, drawing, geometry and arithmetic. "Habia dissegno acio possia dipingere il suo concetto del opera che egli vora fabricare per mostrarlo ad altri quando è bisogno. Habia geome-

Fig. 9. Pio Panfili, Veduta della strada e porta detta di S. Isaia in Bologna (BCABo, Album Panfili, n. 48). The facade of the dormitory of S. Francesco has a serlian window surmounted by an arched window, very similar to that of the dormitory th Michele in Bosco. Pietro Fiorini also worked in the dormitory of in the dormitory
$\mathrm{S}$. Francesco.




tria per che essa è madre del dissegno per sapere pigliare in misura tutti li sitti e tirare le linee rette, le oblique e le circolari, è formare in dissegno qual si voglia fabrica o spaese così in pianta come anco nel alzato. Habia prospettiva per sapere mostrare indissegno qual si voglia cosa in scurtio pigliando alle volte la vista da uno lato è hora dal altro mostrado la forma di quella cosa istessa, ma di vista diferente. Habia aritmetica per potere trovare li conti delle misure delle fabriche, è delle spese da farsi e delle fatte e trovare ancora la proporzione de tutte le cose" (c. 49r).

His training as a painter [Balboni 2019, p. 52] and his documented experience as a surveyor presuppose the knowledge of the principles of practical perspective and, in particular, of the conditions of intersection of the visual pyramid with the perspective plan [24]. In this regard, it is known that as the distance of the point of view from the frame increases, the height $\mathrm{H}$ of a subject increases according to the subtended angle (fig. 8). In the cor-

Fig. 10. Detail of the serlian window designed by Fiorini: the two lateral rectangular openings have superimposed mirroring masonry. The window is surmounted by a large tripartite round arch (on the left the orthophoto elaborated by the lase scanner survey, on the right the dray of elevation, M. Incerti).
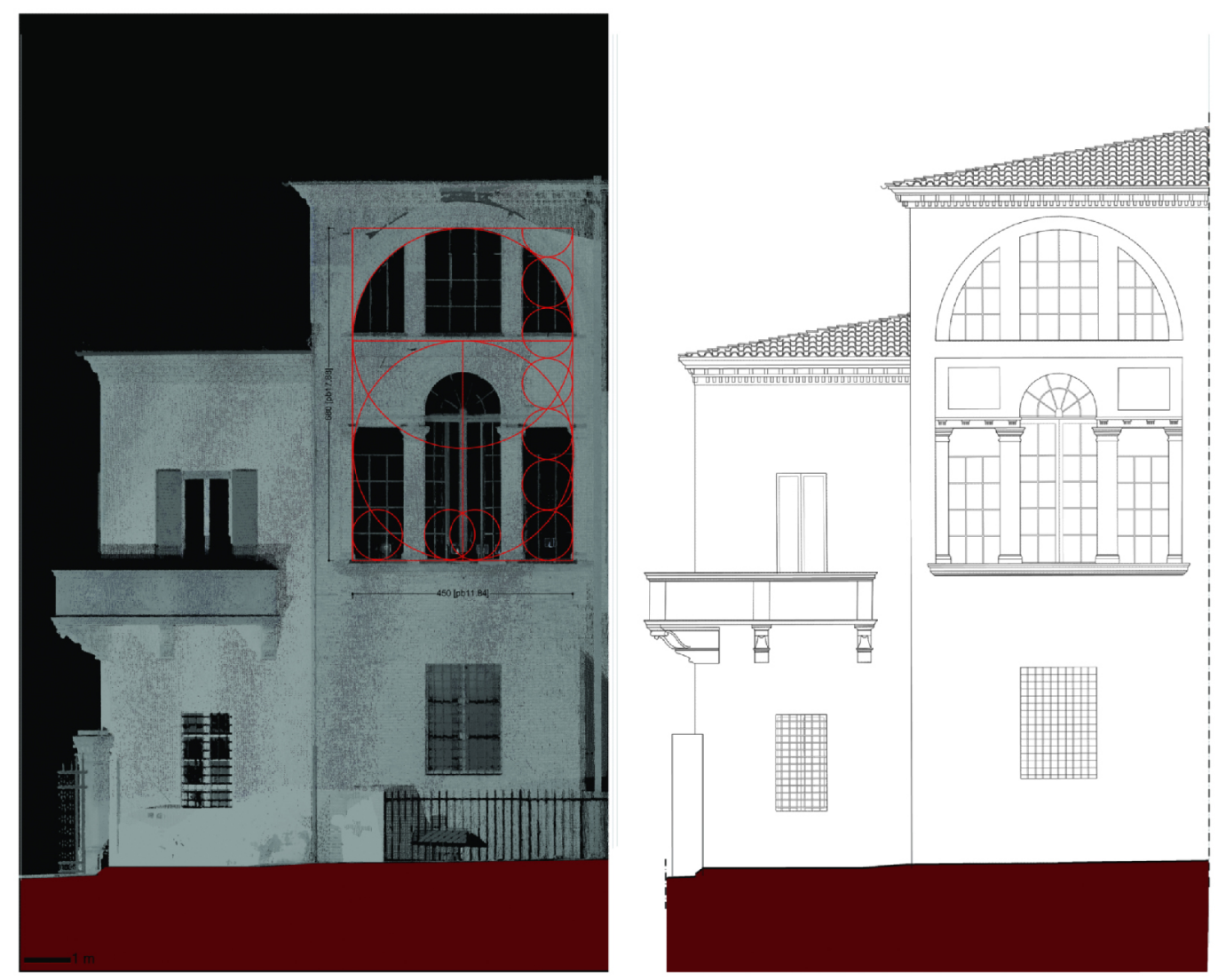

ridor of San Michele in Bosco, the phenomenon becomes perceptually evident [25] only when the entire window enters the visual cone: the rectangular frame, the "Albertian window", is in fact the element of comparison that increases the height of the tower with the distance of the observer. The phenomenon, perhaps less spectacular than it appears today, must have already been known when the mullioned window was present since the central column could easily perform the function of an Albertian "dart".

In conclusion, this great serlian window (figs. 9, 10) was most likely designed by the architect Pietro Fiorini and the surprising visual effect, still visible today, was therefore designed by this Bolognese architect who is still not adequately recognised and studied to this day. 
Fig. I I. The long corridor with back to the city).

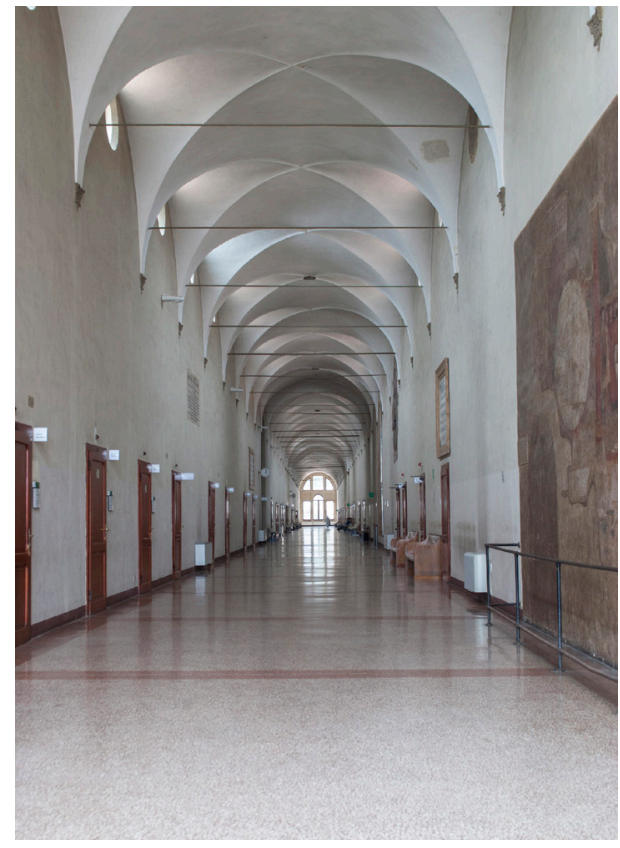

\section{Notes}

[I] S. Michele in Bosco 177/2349, referring to the works from I579 to 1616. Furthermore S. Michele in Bosco 196/5192 published by Minucci 1966, pp. 169 e segg. The abbots are at pp. 192-193.

[2] Zucchini 1954-'55 and now Balboni 2019. The works in S. Michele in Bosco are at pp. 63, 64.

[3] This work was apparently repeated later with the same words, actually the note referred to different and successive moments of the reconstruction of the buildings overlooking the large cloister.

[4] Minucci 1966, p. 192 said in 1596 by vicar di Castro. Don Placido Fava was also abbot of S. Michele in Bosco in I587. Ibidem, p. 193.

[5] Balboni 2019, p. 63; Minucci 1966, p. 193, year 1602.

[6] Minucci 1966, p. 193. It was for multiple years, but the payments to Fiorini bring us back to 1606.

[7] Ibidem noted in they year 1608 and again Cantoni in 1611 .

[8] Ibidem.

[9] S. Michele in Bosco 177/2349, c. 43.

[10] lbidem, c. I02v e segg.].

[ I I] [S. Michele in Bosco 177/2349, c. II I and segs.

[12] Ibidem, c. 116 and segs.] and specifically in c. 1 17v.

[13] See latest Balboni 2019, pp. 54-55] for both the Poggi chapel in S. Giacomo and the octagonal cloister.

[14] Brother of the pontiff Urbano VIII, he died during a mission in Bologna on the 26th of February I630. DBI, 1964, 6.

[15] DBI 1985, 31. Born in Bologna in 1599 and died in the same city in 1647.

[16] Frati 1889, col. II I8 and Medici I853, pp. 865-889 with portrait.

[17]This is the Cena di san Gregorio Magno, from Gesù in casa di Marta e Maria, and a third painting that has been lost, Abramo nella valle di Mambre. The assignment was regulated by a contract signed on February 2, 1539.

[18] The portico to access the church has three arches, one of which was later demolished to create the chapel of Santa Francesca Romana. On the sixteenth-century events of the church see Foschi 2020.

[19] The signature is at the bottom of the north symbol.

[20] Also on the basis of a comparison with the measurements of the laser scanner survey, it is necessary for the side AD to be horizontal.

$[2 I]$ The check with the instrument positioned at a same height from the floor (AD not horizontal) rendered values that are far from those stated in the drawing. 
[22] We thank Eng. Piero Lusuardi (2014).

[23] The measurement was taken on Google Earth with the ruler tool.

[24] Referring to the principles of perspectiva, published in medieval times in works with various titles: Perspectiva, De aspectibus or De visu, used in survey procedures through similar triangles and graduated rods. See Vagnetti 1979, Vescovini Federici 1998.

[25] The phenomenon was studied from a perceptive point of view in Costa 2017.

\section{References}

AA.W. (1997). DBI Dizionario Biografico degli Italiani. Roma: Istituto Treccani.

Alberti L. B. (1568). Opuscoli morali.Venetia:Appresso Francesco Franceschi Sanese.

Balboni V. (2019). «Si è fatto tanto avanti che ha uguagliato li altri» Architetture e scritti di Pietro Fiorini architetto bolognese (I 539-1629). In Quaderni dell'Istituto di Storia dell'Architettura, 70, pp. 39-66.

Costa M., Bonetti L. (20 I7). Linear Perspective and Framing in the Vista Paradox. In Perception, 46, I I, pp. I 245- I 268.

Foschi P. (2020). Incroci padani. Biagio Rossetti, Pellegrino Prisciani e Bologna. In Schifanoia 58-59, 2020, pp. 55-66.

Foschi P. et al. (2017). Monasteri benedettini nella diocesi di Bologna (secoli VII-XV). Bologna: Bononia University Press.

Frati L. ( 1889$)$. Opere della bibliografia bolognese, 2. Bologna: Zanichelli.

Martini A. ( 883). Manuale di metrologia. Torino: Loescher.

Medici M. (1853). Elogio di Paolo Battista Balbi. In Memorie dell'Accademia delle Scienze dell'Istituto di Bologna, IV. Bologna: Tipografia a S. Tommaso d'Aquino.

Minucci P. I. (1966). Aspetti inediti di storia tratti dai regesti d'archivio. Roversi Giancarlo. In San Michele in Bosco. Bologna. Bologna: Poligrafici II Resto del Carlino.

Repishti F. (20I I). «Et si sa che non è architetto aprobato se non nel modo che fanno i principi». Gli esordi di Pellegrino Tibaldi architetto. In F. Ceccarelli, D. Lenzi (a cura di). Domenico e Pellegrino Tibaldi.Architettura e arte a Bologna nel secondo Cinquecento. Venezia: Marsilio.

Vagnetti L. (1979). De naturali et artificiali perspectiva: bibliografia ragionata delle fonti teoriche e delle ricerche di storia della prospettiva: contributo alla formazione della conoscenza di un'idea razionale, nei suoi sviluppi da Euclide a Gaspard Monge. Firenze: L.E.F.

Vescovini Federici G. (1998). Prospettiva (voce). In Enciclopedia dell'arte medievale; <https://www.treccani.it/enciclopedia/prospettiva_\%28Enciclopedia-dell\%27-Arte-Medievale\%29/> (accessed 202I, January 21).

Zucchini G. (1954-55). Un manoscritto autografo dell'architetto Pietro Fiorini. In L'Archiginnasio, XLIX-L, pp. 60-99.

\section{Archives}

ASBo, Archivio di Stato di Bologna, Demaniale, S. Michele in Bosco 177/2349.

ASBo, Archivio di Stato di Bologna, Demaniale, S. Michele in Bosco 196/5192.

ASBo, Periti agrimensori.

BCABo, Biblioteca dell'Archiginnasio di Bologna, Gabinetto Disegni e Stampe.

AABo, Archivio Arcivescovile di Bologna, Fondo Breventani G (I) VIII n I, Diario di Pietro Fiorini.

\section{Authors}

Manuela Incerti, Università degli Studi di Ferrara, manuela.incerti@unife.it

Paola Foschi, Deputazione di Storia Patria per le Province di Romagna, pfoschi@hotmail.it

To cite this chapter. Incerti Manuela, Foschi Paola (2021). Pietro Fiorini e la prospettiva su Bologna/Pietro Fiorini and the perspective on Bologna. In Arena A., Arena M., Mediati D., Raffa P. (a cura di). Connettere. Un disegno per annodare e tessere. Linguaggi Distanze Tecnologie. Atti del $42^{\circ}$ Convegno Internazionale dei Docenti delle Discipline della Rappresentazione/Connecting. Drawing for weaving relationship. Languages Distances Technologies. Proceedings of the $42^{\text {th }}$ International Conference of Representation Disciplines Teachers. Milano: FrancoAngeli, pp. 783-804. 